\title{
Evidence that the Ceratobasidium-like white-thread blight and black rot fungal pathogens from persimmon and tea crops in the Brazilian Atlantic Forest agroecosystem are two distinct phylospecies
}

\author{
Paulo C. Ceresini ${ }^{1}$, Elaine Costa-Souza ${ }^{1}$, Marcello Zala ${ }^{2}$, Edson L. Furtado ${ }^{3}$ and Nilton L. Souza ${ }^{3 \dagger}$ \\ ${ }^{1}$ Departamento de Fitossanidade, Engenharia Rural e Solos, \\ Universidade Estadual Paulista "Júlio de Mesquita Filho", Ilha Solteira, SP, Brazil. \\ ${ }^{2}$ Plant Pathology, Institute of Integrative Biology, Swiss Federal Institute of Technology, Zurich, \\ Switzerland. \\ ${ }^{3}$ Área de Proteção de Plantas, Departamento de Agricultura, \\ Universidade Estadual Paulista “Júlio de Mesquita Filho”, Botucatu, SP, Brazil.
}

\begin{abstract}
The white-thread blight and black rot (WTBR) caused by basidiomycetous fungi of the genus Ceratobasidium is emerging as an important plant disease in Brazil, particularly for crop species in the Ericales such as persimmon (Diospyros kaki) and tea (Camellia sinensis). However, the species identity of the fungal pathogen associated with either of these hosts is still unclear. In this work, we used sequence variation in the internal transcribed spacer regions, including the $5.8 \mathrm{~S}$ coding region of rDNA (ITS-5.8S rDNA), to determine the phylogenetic placement of the local white-thread-blight-associated populations of Ceratobasidium sp. from persimmon and tea, in relation to Ceratobasidium species already described world-wide. The two sister populations of Ceratobasidium sp. from persimmon and tea in the Brazilian Atlantic Forest agroecosystem most likely represent distinct species within Ceratobasidium and are also distinct from $C$. noxium, the etiological agent of the first description of white-thread blight disease that was reported on coffee in India. The intraspecific variation for the two Ceratobasidium sp. populations was also analyzed using three mitochondrial genes (ATP6, nad1 and nad2). As reported for other fungi, variation in nuclear and mitochondrial DNA was incongruent. Despite distinct variability in the ITS-rDNA region these two populations shared similar mitochondrial DNA haplotypes.
\end{abstract}

Key words: ecological speciation, fungal plant pathogens, host specialization, population divergence, phylogenetics.

Received: September 23, 2011; Accepted: January 13, 2012.

\section{Introduction}

The white-thread blight and black rot (WTBR) associated with fungal pathogens from the Ceratobasidium species complex is considered an emerging plant disease for Brazilian crop species in the Ericales, especially persimmon (Diospyros kaki L.) and tea [Camellia sinensis (L.) Kuntze] (Furtado, 1997; Cavalcante and Sales, 2001). However, the species identity of the pathogen associated with either of these hosts is still unclear; it is also unknown whether the fungal pathogens associated with WTBR in persimmon and tea are the same or distinct species. WTBR is particularly important in Brazilian tropical agroecosystems, such as those neighbouring the Amazon and At-

Send correspondence to Paulo C. Ceresini. Departamento de Fitossanidade, Engenharia Rural e Solos, Universidade Estadual Paulista "Júlio de Mesquita Filho", 15385-000 Ilha Solteira, SP, Brazil. E-mail: paulo.ceresini@bio.feis.unesp.br.

${ }^{\dagger}$ Deceased. lantic Forests, because of the high temperatures and humidity that are conducive to disease development (Lourd and Alves, 1987; Gasparotto and Silva, 1999).

The first description of the WTBR pathogen was reported by Cooke in 1876, based on material collected from infected coffee plants in India (Tims et al., 1954). Cooke considered the pathogen a hyphomycete and named it Pellicularia koleroga Cooke 1876. In 1910, Von Hoehnel re-described the pathogen naming the fungus as Corticium koleroga (Cooke) von Höhnel 1910 (Tims et al., 1954). In addition to Corticium koleroga, synonymy of $P$. koleroga has included Botryobasidium koleroga (Cooke) Venkatarayan, Hyphocnus koleroga Stevens \& Hall, Koleroga noxia Donk and Ceratobasidium noxium (Donk) P. Roberts (Venkatarayan, 1949; CAB-International, 2004).

Historically, initiatives for a better taxonomical positioning of the fungal species related to WTBR pathogens were begun by Rogers (1943), who positioned P. koleroga within the Botryobasidium complex. Donk (1954) pro- 
posed the monotypic genus Koleroga to accommodate $P$. koleroga (characterized by secondary spores and tetra-spored basidia). Talbot (1965) considered the genus Pellicularia as a synonym of Ceratobasidium; other species with secondary spores were transferred from Botryobasidium to the genera Thanatephorus and Uthatobasidium. While one of the most important species within Thanatephorus (T. cucumeris) is a pathogen for several plant species (Sneh et al., 1991), the Botryobasidium complex (which includes Botryohypochnus and Uthatobasidium) is basically composed of wood decomposing fungal species. Currently, the white-thread blightcausing species of several tree plants are grouped within the genus Ceratobasidium, more precisely $C$. anceps, C. cornigerum and C. noxium (Roberts, 1999).

The first report of WTBR caused by Ceratobasidium in Brazil dates back to 1978 when the occurrence of a white-thread blight-like fungal pathogen was observed in a Pomelo [Citrus maxima (Merr., Burm. f.)] orchard in the Amazon region. The pathogen associated with this disease was identified as P. koleroga (Rosseti et al., 1982). Lourd and Alves (1987) reported that 27 plant species were hosts for this pathogen in the Amazon. Another 18 species of native fruit trees from the Amazon were subsequently described as hosts for P. koleroga (Gasparotto and Silva, 1999). Among these host species, WTBR has been reported to affect soursop (Annona muricata L.), black-pepper (Pipper nigrum L.), cacao (Theobroma cacao L.), Citrus sp., coffee (Coffea arabica L), mango (Mangifera indica L.), rubber trees [Hevea brasiliensis (Willd. Ex Adr. de Juss.) Muell. \& Arg.] and several other tree species (Fawcett, 1914; Rosseti et al., 1982; Furtado, 1997; Pereira et al., 2000; Benchimol et al., 2001). WTBR has also been reported to affect several tree crops worldwide and occurs on most continents. In the Americas, WTBR has been reported in Argentina, Brazil, Columbia, Venezuela, and the Guianas, in several Central American countries, Mexico and the United States (Tims et al., 1954; CAB-International, 2004). These Ceratobasidium-associated diseases have recently been reported to affect persimmon (whitethread blight) and tea (black-rot) in areas near the Atlantic Forest agroecosystem of São Paulo State, such as Guararema, in the Mogi das Cruzes region (Pereira et al., 2003) and Registro, in the Vale do Ribeira (Ribeira River Valley) (Furtado, 1997), respectively. Signs of the pathogen and symptoms of the disease on persimmon and tea are shown in Figure S1.

In Brazil, there are several tree species for which the identity of the fungal pathogen that causes white-thread blight is unknown (Lourd and Alves, 1987). We are particularly interested in resolving the phylogenetic placement of the Ceratobasidium species associated with persimmon and tea from the Brazilian Atlantic Forest agroecosystem. This is the first study to establish the identity of the pathogen(s) associated with WTBR on these Brazilian crops.
Similarly, there is no information on the recent levels of intraspecific genetic variation in these two populations of Ceratobasidium sp. or on the extent of recent or historical genetic divergence between the persimmon- and tea-derived populations of the pathogen.

DNA sequence information from ribosomal DNA (rDNA) genes and their transcribed spacer regions (ITS1 and 2) has been extensively used to establish the relationship among distinct and closely related taxa within the Ceratobasidium complex by phylogenetic methods (Gonzalez et al., 2001). Variation in the rDNA genes has also been used for studies of fungal population divergence to determine the population-species interface (White et al., 1990; James et al., 2001; Ciampi et al., 2005).

In contrast to nuclear genes, fungal mitochondrial DNA (mtDNA) has accumulated much fewer changes compared with mammalian mtDNA (Clark-Walker, 1991). However, no intraspecific studies have surveyed nuclear and mitochondrial variation in any Ceratobasidium species or even among sister species of the important plant pathogenic genus Thanatephorus. There is currently no information as to whether the variation in mtDNA regions is less than or equal to that for nuclear genes in these fungi.

The initial objective of this study was to use sequence variation in the ITS-5.8S region of rDNA to determine the phylogenetic placement of the local white-thread-blightassociated populations of Ceratobasidium sp. from persimmon and tea in relation to Ceratobasidium species already described around the world. We also analyzed the intraspecific sequence variation in nuclear rDNA (ITS1, ITS2 and 5.8S) to test the hypothesis that the two distinct populations of Ceratobasidium (one in each host) represent a single species with a very low level of recent or historical divergence between them. The intraspecific variation in the two Ceratobasidium sp. populations from tea (Cs) and persimmon (Dk) was analyzed using a previously sequenced coding region from the mitochondrial gene coding for ATP synthase 6 (ATP synthase subunit 6, ATP6 (Kretzer and Bruns, 1999) and two others from two mitochondrial NADH dehydrogenase genes (NADH dehydrogenase subunit 1, nad1, and subunit 2, nad2). The NADH subunit sequences were obtained specifically for this study based on sequences of ortholog genes from other Basidiomycota. Since fungal mtDNA has a lower mutation rate than nuclear DNA (Clark-Walker, 1991) we hypothesized that the variation in mtDNA in Ceratobasidium sp. would be lower than in nuclear DNA.

\section{Materials and Methods}

\section{Population samples}

Two populations of the WTBR fungal pathogen Ceratobasidium sp. were sampled. One population was obtained from persimmon "Rama Forte" in Guararema ( $\left.23^{\circ} 32^{\prime} 32^{\prime} \mathrm{S}, 46^{\circ} 12^{\prime} 00^{\prime \prime} \mathrm{W}\right)$, in the Mogi das Cruzes re- 
gion, São Paulo state (SP), Brazil, in February 2005. The other population was obtained from tea "IAC 259" in Registro $\left(24^{\circ} 29^{\prime} 15^{\prime}\right.$ ' S, $47^{\circ} 50^{\prime} 37^{\prime}$ ' W), in the Vale do Ribeira region (SP) (Figure 1). The samples were collected from infected actively growing vegetative material from adult plants; 10-12 disease foci were sampled from transects along the fields and 5-6 infected branches were collected from each focus. Thirty-one isolates were obtained from persimmon and another 31 from tea. The isolates were initially obtained using alkaline water agar $(\mathrm{pH} 8.5)$ with subsequent transfer of fungal hyphal tips to potato-dextrose agar (PDA, Difco) (Gutierrez et al., 1998). For long-term storage, four-day-old fungal colonies grown on potatodextrose agar supplemented with $50 \mu \mathrm{g}$ of kanamycin $/ \mathrm{mL}$ were transferred to sterilized parboiled rice (containing $50 \mu \mathrm{g}$ of chloramphenicol $/ \mathrm{mL}$ ), grown for about five days at $25^{\circ} \mathrm{C}$, air-dried under laminar-flow for two days and finally preserved at $-20^{\circ} \mathrm{C}$ (Ceresini and Souza, 1996). Four extra isolates (from persimmon, tea, soursop and mango) previously obtained in our lab were included in the sample. All isolates showed typical Ceratobasidium growth on potato-dextrose-agar and were characterized as binucleate by classic cytomorphological methods (Herr and Roberts, 1980; Sneh et al., 1991; Ceresini and Souza, 1996).

\section{DNA extraction}

Fungal mycelia for DNA extraction were produced by growing the Ceratobasidium isolates in $25 \mathrm{~mL}$ of $\mathrm{PD}$ broth supplemented with kanamycin $(50 \mu \mathrm{g} / \mathrm{mL})$ in $50 \mathrm{~mL}$ Falcon tubes (Greiner Bio-one, Germany). After five days of incubation at $25^{\circ} \mathrm{C}$ on a rotor-shaker at $180 \mathrm{rpm}$, the my- celia were harvested, frozen and lyophilized. Total DNA was extracted from lyophilized mycelial tissue using DNeasy Plant mini extraction kits (Qiagen, Hilden, Germany) according to the manufacturer's instructions.

\section{PCR amplification and sequencing of the ITS region of rDNA}

Polymerase chain reactions (PCR) to amplify the ITS1-5.8S-ITS2 rDNA region were done on a Biometra T-Gradient thermocycler (Göttingen, Germany) in $20 \mu \mathrm{L}$ reactions containing 20-50 ng of total DNA, $2 \mu \mathrm{L}$ of $10 \mathrm{X}$ reaction buffer $\left(100 \mathrm{mM} \mathrm{KCl}, 100 \mathrm{mM}\left(\mathrm{NH}_{4}\right)_{2} \mathrm{SO}_{4}\right.$, $200 \mathrm{mM}$ Tris- $\mathrm{HCl}, 20 \mathrm{mM} \mathrm{MgSO}_{4}, 1 \%$ Triton X-100, pH 8.8; NEB [New England Biolabs]), $0.5 \mu \mathrm{M}$ of each primer (ITS4/ITS5; White et al., 1990), $0.1 \mathrm{mM}$ of each dNTP and 0.5 units of $T a q$ polymerase (NEB - New England Biolabs). The PCR conditions were $96{ }^{\circ} \mathrm{C}$ for 2 min, 35 cycles of denaturation for $1 \mathrm{~min}$ at $96{ }^{\circ} \mathrm{C}$, annealing for $1 \mathrm{~min}$ at $55^{\circ} \mathrm{C}$ and elongation for $1 \mathrm{~min}$ at $72^{\circ} \mathrm{C}$. The extension time of the final cycle was $5 \mathrm{~min}$. The PCR products were purified using Nucleofast-96-PCR clean-up plates (MachereyNagel, Germany).

The ITS-5.8S region of rDNA was sequenced using a pre-mixed kit for cycle-sequencing based on dye-terminator chemistry (ABI-PRISM Big-Dye Terminator v. 3.0 Cycle Sequencing Ready Reaction, Applied Biosystems, USA) according to the manufacturers instructions. Around $50 \mathrm{ng}$ of purified PCR amplicon DNA and $1 \mu \mathrm{M}$ of each of the primers (ITS4 and ITS5) were used in each of two independent sequencing reactions. The sequencing products were separated by electrophoresis in the 16-capillary array

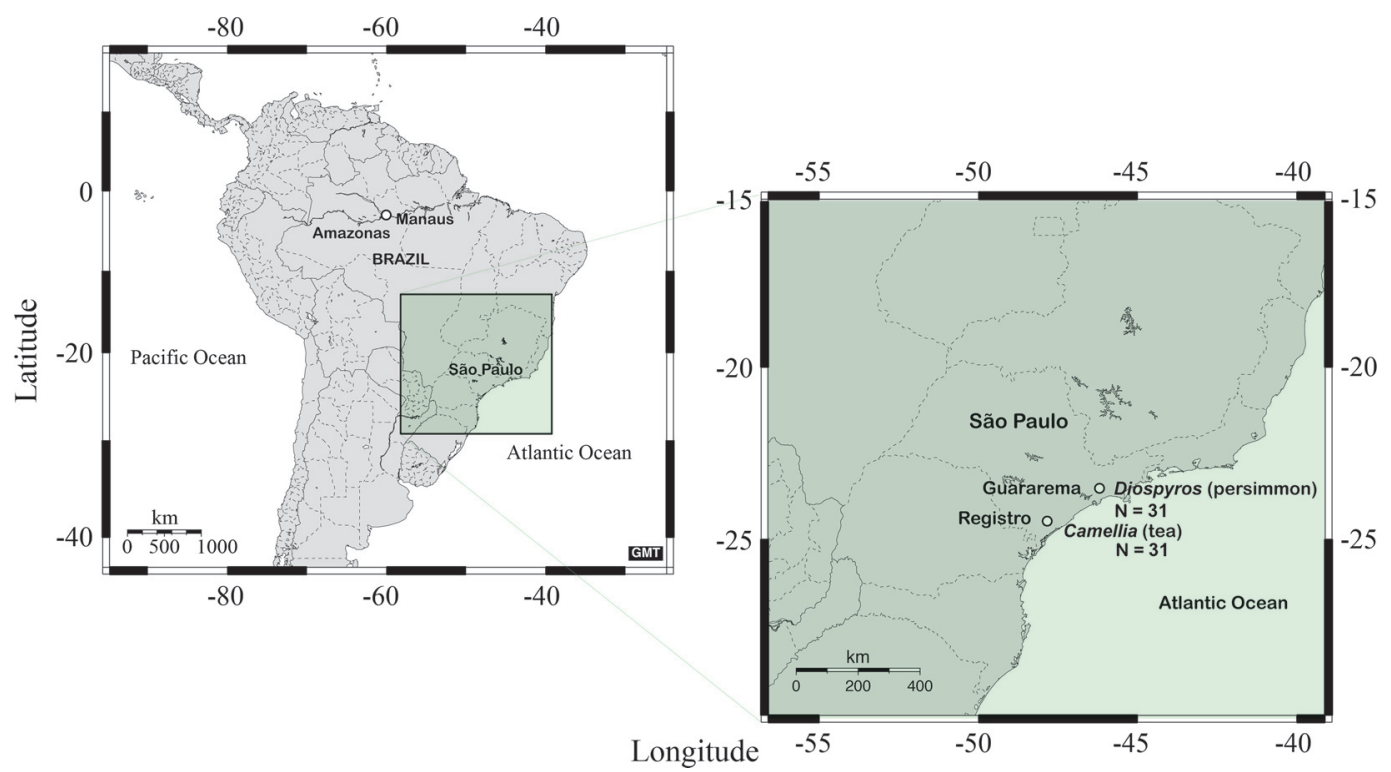

Figure 1 - Geographic origin of Ceratobasidium sp. isolates obtained from persimmon (Diospyros kaki, Ericales, Ebenaceae) and tea (Camellia sinensis, Ericales, Theaceae) in São Paulo state, Brazil. White-thread blight diseased persimmon plants were sampled in Guararema while black-rot infested tea plants were collected in Registro. Both sampling locations belong to the Brazilian Atlantic Forest agroecosystem. Four extra isolates obtained from persimmon and tea in São Paulo and from mango (Mangifera indica, Sapindales, Anacardiaceae) and soursop (Anonna muricata, Magnoliales, Annonaceae) in Manaus, Amazonas, Brazil, were included in the analyses. 
of an automated ABI-3100 sequencer (PE Applied Biosystems) using a POP6 separation matrix (Applied Biosystems). The sequences obtained were analyzed for quality, base content and contig assembly using the software Sequencher 4.5 (Gene Code Corporation, Ann Arbor, MI, USA).

\section{Cloning of PCR amplicons}

The predominant heterokaryotic condition in the Ceratobasidium life cycle means that heterokaryotic in the DNA sequences from non-cloned PCR amplicons is commonly observed. To separate distinct alleles of the ITS-5.8S rDNA operon from the same heterogeneous PCR product the heterogeneous amplicons were cloned into the vector PCR2.1-TOPO (Invitrogen). Selected recombinant plasmids from Escherichia coli One Shot DH5a-T1R (Invitrogen) were extracted from each one of the cloned heterogeneous samples and purified using QIAprep Spin Miniprep kits (Qiagen). Primers for one of the multiple cloning sites of the vector were used for reamplification and sequencing.

Cloning of nad1 and nad2 orthologs and mitochondrial haplotyping using nad1, nad2 and ATP6 genes

Orthologous sequences from two mitochondrial genes (nad1 and nad2) from the Basidiomycota fungi Crinipellis perniciosa (NCBI accession number AY376688), Cryptococcus neoformans var. grubii (NC_004336 and AY560608) and Schizophylum commune (NC_003049) available at GenBank/NCBI were aligned and used to design degenerate primers targeting conserved regions of the two loci. Fungal genomic DNA was amplified with degenerate primers designed from the nadl and nad2 sequences (see Table S1). The PCR conditions were the same as described above and the products were separated by electrophoresis on a $0.8 \%$ low-melting agarose gel. Amplicons of the expected size were cut from the gel and cloned into the vector PCR2.1-TOPO and transformed in E. coli One Shot DH5a-T1R. Positive colonies were selected and the plasmid DNA was purified and sequenced as described above. Specific primer pairs designed from conserved regions were able to amplify sequences encoding nadl and nad 2 from Ceratobasidium and its sister genus Thanatephorus.

In addition to $\mathrm{nad} 1$ and $\mathrm{nad} 2$, another mitochondrial gene (ATP6) was used for mitochondrial haplotyping of Ceratobasidium sp. populations from persimmon and tea. The Basidiomycota ATP6-specific primers used in this study were the same as those recommended by Kretzer and Bruns (1999).

\section{Data analysis}

Initially, the sequences of the ITS-5.8S rDNA region from the Brazilian isolates of Ceratobasidium sp. were compared with Ceratobasidium spp. sequences deposited in GenBank/NCBI. Similarity comparisons among sequences were done using BLASTN (nucleotide-nucleotide) version 2.2.12 (Altschul et al., 1997).

\section{Phylogenetic analyses}

For the phylogenetic analyses, we included sequences of the ITS-5.8S rDNA region retrieved from GenBank/NCBI for the following species of Ceratobasidium: C. albasitensis, $C$. anceps, C. angustisporum, C. bicorne, C. cereale (R. cerealis), $C$. cornigerum, $C$. papillatum and C. ramicola. These sequences shared $78 \%-86 \%$ identity with the ITS-5.8S rDNA sequences from the Brazilian Ceratobasidium isolates from persimmon and tea. All of the sequences were aligned using the program ClustalX (Thompson et al., 1994, 1997). We also included a sequence of the ITS-5.8S region of $C$. noxium type strain (CBS154-35) introduced from CBS (Centraalbureau voor Schimmelcultures, The Netherlands).

The phylogenetic analyses were done using maximum likelihood (ML), maximum parsimony (MP) and Bayesian methods. For both ML and MP analyses, the software PAUP $4.0 \mathrm{~b} 10$ was used (Swofford, 2002). The Bayesian analysis was done using the metropolis coupled Monte Carlo Markov Chain algorithm (MCMCMC), implemented in MrBayes v. 2.10 (Huelsenbeck and Ronquist, 2001).

For the ML and MCMCMC analyses, MODELTEST 3.7 (Posada and Crandall, 1998) was used to determine the model of nucleotide evolution that best fitted the data. A hierarchical likelihood ratio test implemented by MODELTEST selected the model GTR $+\mathrm{G}+\mathrm{G}$ (proportion of invariable sites $=0.4309$; base frequencies: $\mathrm{A}=0.3097$, $\mathrm{C}=0.2189, \mathrm{G}=0.2226$ and $\mathrm{T}=0.2488$; substitution rates $\mathrm{R}[\mathrm{A}-\mathrm{C}]=0.3423, \mathrm{R}[\mathrm{A}-\mathrm{G}]=5.1103, \mathrm{R}[\mathrm{A}-\mathrm{T}]=0.4034$, $\mathrm{R}[\mathrm{C}-\mathrm{G}]=0.0 .0381, \mathrm{R}[\mathrm{C}-\mathrm{T}]=5.1103, \mathrm{R}[\mathrm{G}-\mathrm{T}]=1$, and gamma distribution shape parameter $=0.7787)$. Under this model for base substitution, the ML value for the tree was $-\ln (\mathrm{L})=1835.11$.

The parsimony analysis was done by weighting all bases equally and treating indels as missing data. One hundred and nine of the characters were parsimony informative. Heuristic searches were done with maxtrees set to automatically increase, random taxon addition and TBR branch swapping (839 trees with scores $\geq 295$ were saved). Bootstrap analysis was used to determine the statistical support for each branch of the trees generated (for ML and MP optimality criteria) with 1,000 pseudo-replications in which all characters were re-sampled in each replication.

The phylogenetic analysis by MCMCMC was done using the a priori model of nucleotide evolution selected by MODELTEST. We searched for 3,000,000 generations using four chains and eliminated the first 250 trees as burning; one tree in every 500 sampled was stored. Posterior proba- 
bility values (PP) were generated from a $50 \%$ majority rule consensus tree of 6,000 saved trees.

Intraspecific evolution of Ceratobasidium sp. populations from persimmon and tea inferred by analysis of a haplotype network

To infer intraspecific evolution, networks of haplotypes sampled from populations of Ceratobasidium sp. from persimmon and tea were built using the algorithm recommended by Posada and Crandall (2001) and the "shareware" TCS developed by Clement et al. (2000). This method starts by estimating the maximum number or differences between haplotypes as a result of single substitutions (i.e., those not resulting from multiple substitutions in a single site) with a statistical significance level of $95 \%$ (Templeton et al., 1992). This is called the limit of parsimony or the limit of parsimony connection. Haplotypes differing by only one change are then connected, followed by those differing by two, three and so on until all of the haplotypes are included in a single network, or until the limit of parsimony connection is reached. The estimation of phylogeny from DNA sequences was done using TCS (Clement et al., 2000).

\section{Test for population subdivision and coalescent analysis}

We used the SNAP Workbench Java program package to analyze gene genealogies and population parameters (Price and Carbone, 2005). SNAP Map was used to collapse sequences into haplotypes and to remove indels and infinite sites violations among the mutations (Aylor et al., 2006). Coalescent methods make strict assumptions, such as neutrality and a lack of recombination, that must be verified beforehand. To test for departures from neutrality, Tajima's D (Tajima, 1989) and Fu and Li's D and F* (Fu and $\mathrm{Li}, 1993$ ) test statistics were calculated using the statistical tests of neutrality of mutations against an excess of recent mutations (rare alleles).

SNAP Clade and SNAP Matrix were used to screen the variable sites and identify those showing homoplasy (Figure 2). To generate compatible sequence alignments for coalescent analysis, Carbone and Kohn (2001) suggested the removal of haplotypes whereas Stukenbrock et al. (2007) suggested the manual removal of conflicting sites in each gene alignment; we used the latter approach. 17 polymorphic sites were removed from the dataset [13 incompatible sites (see Figure 2), one that violated the infinite sites model and three that were invariable after removal of the Amazonian haplotypes (HCs05 and HCs11); see Table S2 for details], resulting in 32 compatible polymorphic sites after manipulation of the alignments. To determine the order of coalescent events for haplotypes backward in time it is necessary to determine the amount of migration that occurred between populations. Haplotypes from populations linked by migration are postulated to coalesce before ha-

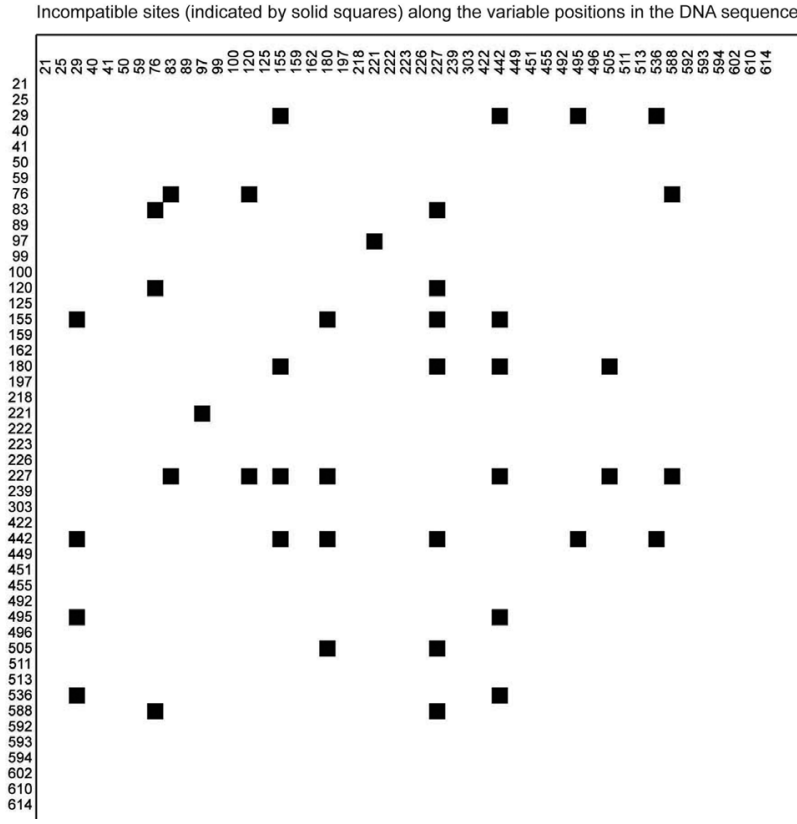

Figure 2 - Site compatibility matrices for Ceratobasidium sp. homoplasious ITS-rDNA haplotypes from persimmon and tea. The numbers along the top and the left of the matrix indicate variable positions in the DNA sequence alignments and the left of the matrix of the data. Incompatible sites are indicated by solid squares; all other sites in the matrix are compatible.

plotypes from unlinked populations (Carbone and Kohn, 2001). The program MIGRATE 2.1.3 (Beerli and Felsenstein, 2001) was used to construct a migration matrix that indicated the number of migrants exchanged between populations. This backward migration matrix was used for ancestral inference in Genetree version 9.0 (Griffiths and Tavaré, 1994, 1996) and was also incorporated in the SNAP Workbench. Subsequently, we reconstructed the genealogy with the highest root probability, the ages of mutation and the $T_{\mathrm{MRCA}}$ (time to the most recent common ancestor) of the samples using 100,000 coalescent simulations with five runs that had distinct starting random number seeds; this analysis took into consideration population subdivision and assumed populations of the same size. The program allows estimation of the ancestral history of each haplotype and shows the distribution of mutations on a coalescent scale, thus allowing for comparison of the divergence of haplotypes within and between each population.

Population size fluctuation $\left(\theta_{t}\right.$ and $\left.\theta_{\text {now }}\right)$, demographic parameters $\left(N_{\mathrm{e}}\right)$ and the migration rates for each population $\left(M_{\text {Lamarc }}=\mathrm{m} / \mu\right)$ were tested using an MCMC method implemented by the computer program LAMARC 2.1 (Kuhner, 2006; Kuhner and Smith, 2007). We used the initial parameters of gene flow among populations with the migration rates obtained with MIGRATE 2.1.3 (Beerli and Felsenstein, 2001). Our search strategy included 10 replicates of 10 initial chains and five long final chains. The initial chains were constructed with 500 samples and a 
sampling interval of 20 (10,000 steps), using a burn-in of 1000 samples for each chain. The five final chains were constructed with 5,000 samples and a sampling interval of 200 (1,000,000 steps) and a burn-in of 10,000. The confidence interval for theta $(\theta)$ and growth rate $(g)$ was calculated using the percentile approach. The ancestral $N_{\mathrm{e}}$ at ' $t$ ' time ago was calculated using the following equation for population growth: $\theta_{t}=\theta_{\text {now }} e^{-\mathrm{gt}}$, where ' $\theta$ ' represents a measure of effective population size (for diploids, theta $=4 N_{\mathrm{e}} \mu, \mu$ is the mutation rate inferred for the locus), ' $t$ ' is the time in mutational units and ' $g$ ' is the exponential growth parameter.

We also used the Bayesian skyline plot method implemented in the program BEAST 1.2 (Drummond et al., 2005; Drummond and Rambaut, 2006) to estimate the time dynamics of population size fluctuation. This Bayesian method uses an MCMC integration under a coalescent model to incorporate uncertainty in the genealogy, where the timing of divergence dates provides information about the effective population sizes through time. The $T_{\mathrm{MRCA}}$ for all sequences and for the two major clades (Camellia and Diospyrus) were also estimated using two clock rate values: $8.806 e^{-4}$ and $16.983 e^{-4}$ substitutions/gene* $10^{3}$ years which are, respectively, the average and the highest substitution rates proposed for the ITS-rDNA region in fungi (Kasuga et al., 2002).

\section{Analysis of mitochondrial haplotype diversity}

We estimated the level of mtDNA polymorphism at three loci (ATP6, nad1 and nad2) by determining the number of polymorphic sites, the average number of nucleotide differences $(\mathrm{k})$ between two haplotypes and the sharing of haplotypes between the two populations of Ceratobasidium sp. (Cs and Dk). The divergence between the Cs and Dk populations was contrasted with that between two sister phylospecies within the Thanatephorus complex (which has $R$. solani anamorphs): $R$. solani anatomosis group AG-1 IA ( $R s$ AG-1 IA) and IB (Rs AG-1 IB). The measurement and DNA sequence variation within and between populations of Ceratobasidium sp. and the comparison between Ceratobasidium and Thanatephorus were done using DnaSP v. 4.0 (Rozas et al., 2003).

Table $\mathrm{S} 1$ shows the primers used to amplify the three mtDNA loci and Table S2 provides more information on the haplotype polymorphisms along the ITS-rDNA region of Ceratobasidium sp from persimmon and tea. Sequences from the ATP6, nad1 and nad2 haplotypes detected in this study were deposited in GenBank/NCBI under the following accession numbers: EU810057 to EU810092 (ATP6), EU810093 to EU810128 (nad1) and EU810129 to EU810156 (nad2).

\section{Results}

All 62 isolates obtained from persimmon and tea and also the isolates from mango and soursop had ITS-5.8S
rDNA sequences similar to the Ceratobasidium spp. deposited in GenBank/NCBI. Thirty-nine distinct haplotypes were identified among the global database of ITS-5.8S rDNA sequences from Ceratobasidium spp., which included those originating from persimmon, tea, mango, soursop, the CBS type strain of C. noxium (CBS 154-35) from coffee in India and others derived from several Ceratobasidium species and retrieved from GenBank, such as: $C$. albasitensis $(\mathrm{H} 15)$, C. raminicola $(\mathrm{H} 17)$, C. cereale $(\mathrm{H} 04$, $\mathrm{H} 06$ to H12), C. cornigerum (H03, $\mathrm{H} 20$ to H25), C. bicorne (H13), C. angustisporum (H16), C. anceps (H05) and C. papilatum (H14). The Ceratobasidium sp. isolates from persimmon, tea, mango and soursop were grouped into 17 distinct haplotypes: $\mathrm{H} 01$ and H02, H18 and H19, and $\mathrm{H} 26$ to H38 (Table 1, phylogenetics item). The ITS-5.8S sequence from $C$. noxium (CBS 154-35) was characterized as haplotype $\mathrm{H} 39$, distinct from all the other Ceratobasidium sequences isolated from persimmon and tea.

A comparison of the ITS-5.8S rDNA sequences from Brazilian Ceratobasidium identified 28 haplotypes (Table 1 , reticulate phylogeny item). This increase in haplotype numbers from 17 to 28 was attributable to several polymorphic sites present only in the Brazilian sample. Haplotype 14 was excluded from the subsequent phylogenetic analyses because of its incomplete ITS-5.8S rDNA sequence. In a separate analysis of the Brazilian sample of Ceratobasidium, 20 haplotypes were found to originate mainly from tea (but also included isolates from mango and soursop) and eight were found in the persimmon sample (Table 1).

Of the 31 Ceratobasidium sp. isolates from tea, 29 $(93.5 \%)$ were heterokaryons, with two distinct alleles detected for the ITS-5.8S in each isolate. The isolate from mango was also a heterokaryon, while that from soursop had only a single allele for this rDNA region. In contrast, $71 \%$ of the Ceratobasidium isolates from persimmon (a total of 22) were heterokaryons. A single isolate, obtained in an earlier sample, was a homokaryon. No ITS-5.8S rDNA haplotypes were shared by isolates from the persimmon and tea populations.

\section{Phylogenetic analyses}

The ML tree indicated that the ITS-5.8S rDNA haplotypes of Ceratobasidium sp. from persimmon and tea constitute an independent clade relative to all the other species of Ceratobasidium analyzed, including $C$. cornigerum, $C$. cereale, $C$. anceps, $C$. bircorne and $C$. noxium. The species $C$. albasitensis and $C$. raminicola were used as outgroups for rooting the trees (Figure 3). The topologies of the ML, MP and Bayesian trees were congruent.

In addition to assessing the global phylogenetic position of our samples relative to the other species of Ceratobasidium described worldwide, we examined whether the population of white-thread-blight Ceratobasidium sp. from persimmon was similar to the 


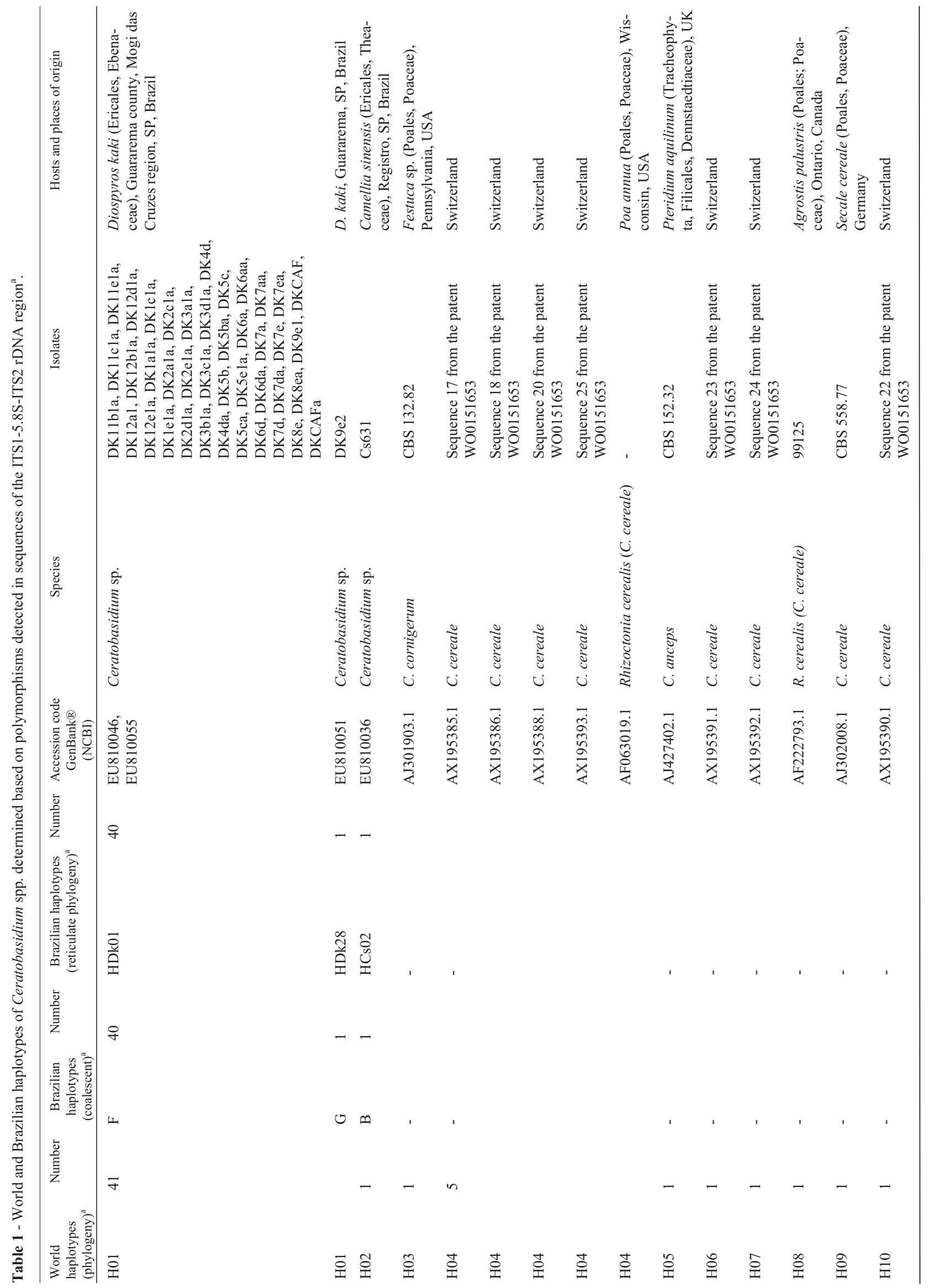




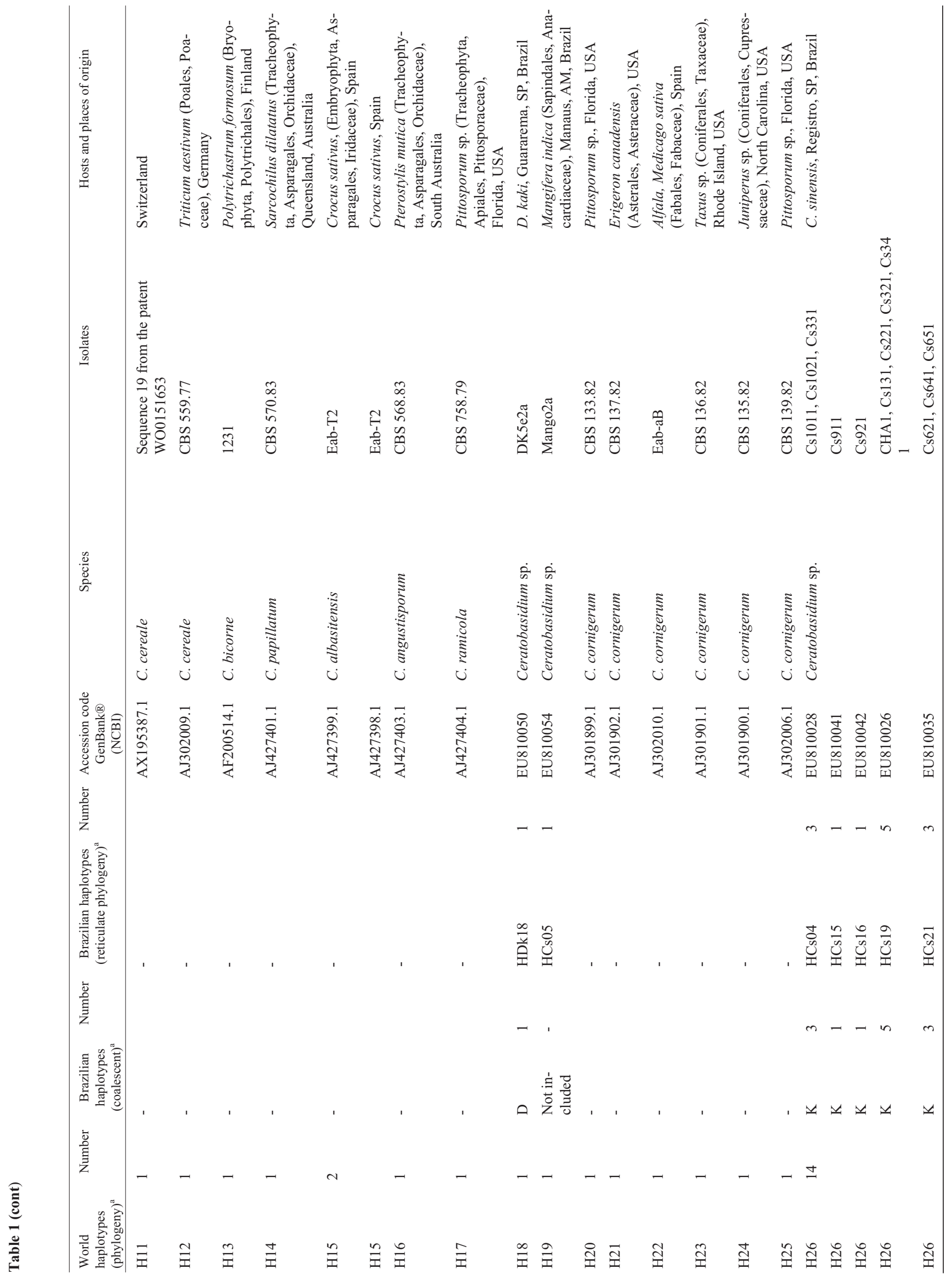




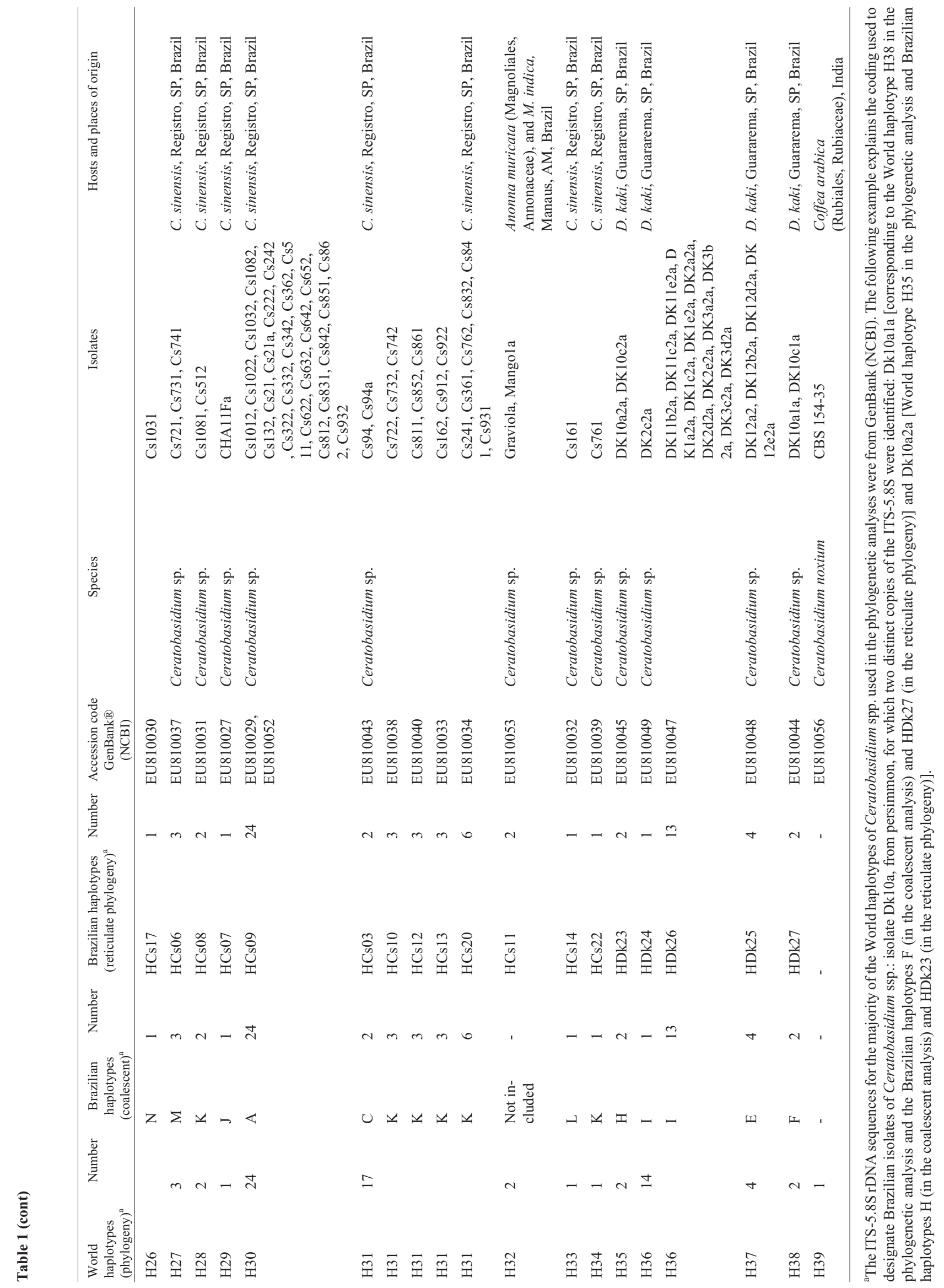


species causing black rot on tea in the Vale do Ribeira. In this context, the ML tree (Figure 3) revealed two distinct main clades that grouped the ITS-5.8S haplotypes of Ceratobasidium sp. essentially according to their host of origin. While the persimmon-associated clade consisted exclusively of haplotypes from persimmon isolates collected in São Paulo, the tea-associated clade contained haplotypes identified in isolates of Ceratobasidium from tea, mango and soursop, indicating that this last clade may be more widespread in Brazil, particularly in native plant populations.

\section{Intraspecific evolution of Ceratobasidium sp. from persimmon and tea inferred by analysis of reticulate haplotype networks}

The statistical parsimony analyses of ITS-5.8S rDNA haplotypes from Ceratobasidium sp. from persimmon and from tea, mango and soursop isolates indicated two distinct, unconnected networks (Figure 4). The
Ceratobasidium sp. population from the Camellia-associated clade was more diverse as judged by the number of ITS-5.8S haplotypes that formed the statistical parsimony network (20 haplotypes). In contrast, the Diospyros-associated clade consisted of eight haplotypes. The most frequent haplotype in the network from the Camellia-associated clade was HCs9 $(\mathrm{n}=24)$, while for the Diospyros clade the most frequent haplotype (from which all the ramifications of the network were derived) was HDk1 $(n=40)$.

\section{Test for population subdivision and coalescent analysis}

Table 2 provides evidence for the non-neutral evolution of ITS-rDNA in the population of Ceratobasidium from tea. The significant values of $\mathrm{Fu}$ and $\mathrm{Li}^{\prime} \mathrm{S} \mathrm{F}$ * and $\mathrm{D}^{*}$ were negative. A significant negative test result is consistent with either population growth or shrinkage or background selection (Fu, 1997). Since the ITS and IGS are the regions of rDNA with the lowest selective constraint [fully

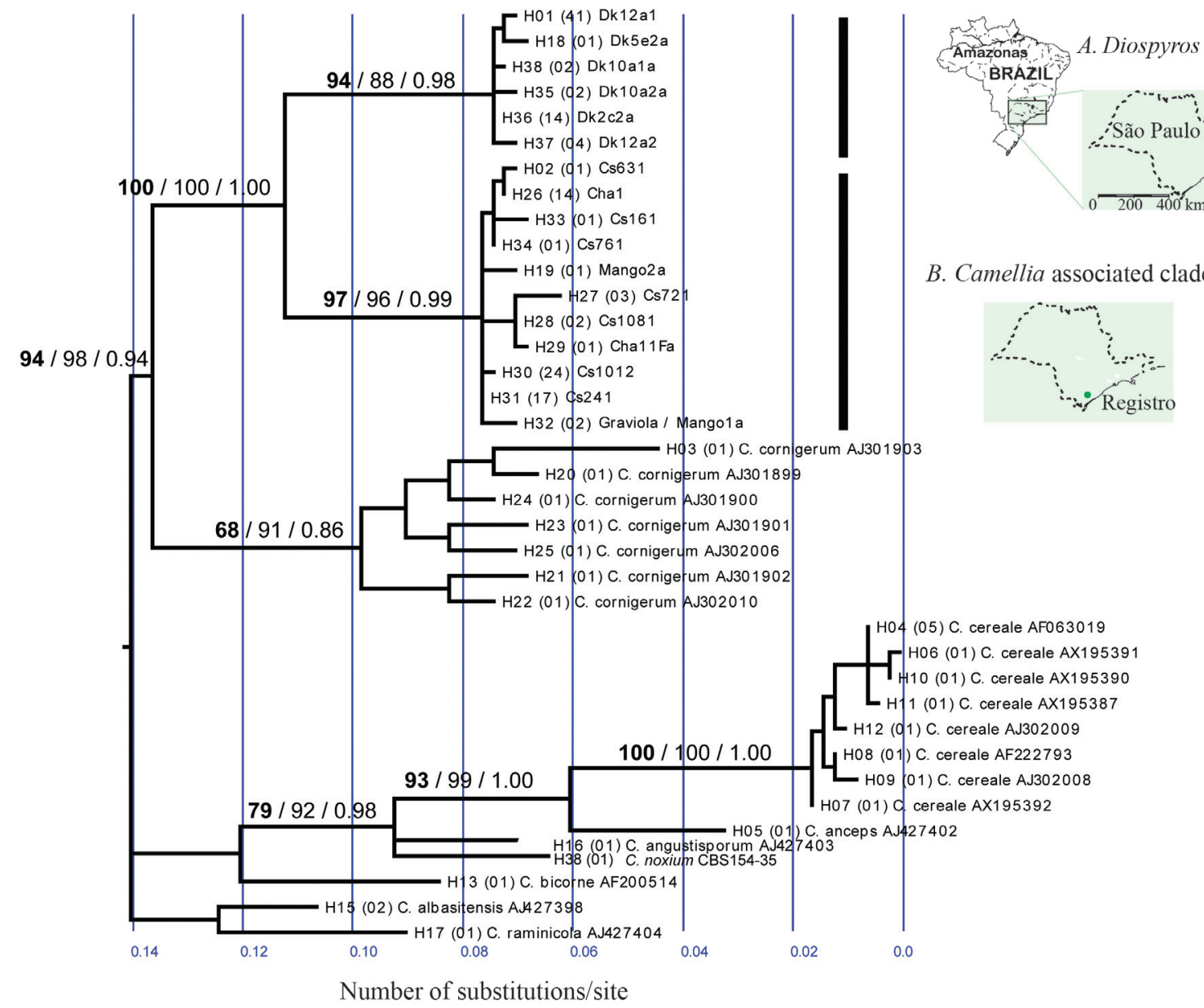

Figure 3 - Maximum likelihood (ML) tree showing the phylogenetic relationship among Ceratobasidium spp. based on the GTR $+\mathrm{G}$ evolutionary model. ML (bold), maximum parsimony (regular type) 1,000 replicate bootstrap values and Bayesian MCMCMC posterior probabilities (closer to 1.0) are given for the major clades. The taxon unit identifications consist of the ITS-5.8S rDNA haplotype designation followed by the number of haplotypes sampled, the species of Ceratobasidium, the code of representative isolates belonging to a particular haplotype and/or the code number for sequences obtained from GenBank/NCBI. The haplotype designations for Ceratobasidium spp. are given in Table 1. The tree was rooted using the ITS-5.8S-rDNA sequences from C. albasitensis and C. raminicola. 
A. Diospyros associated clade

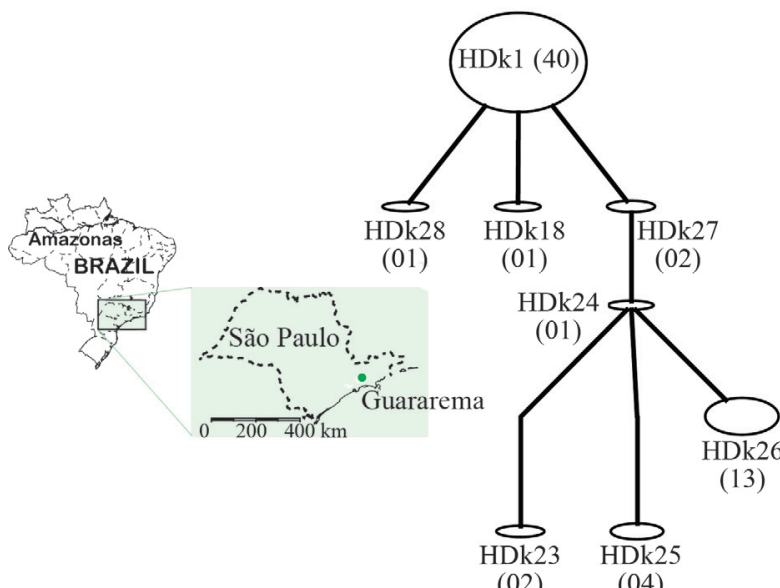

$(02)$

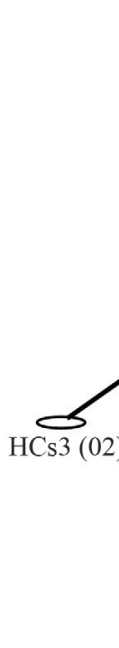

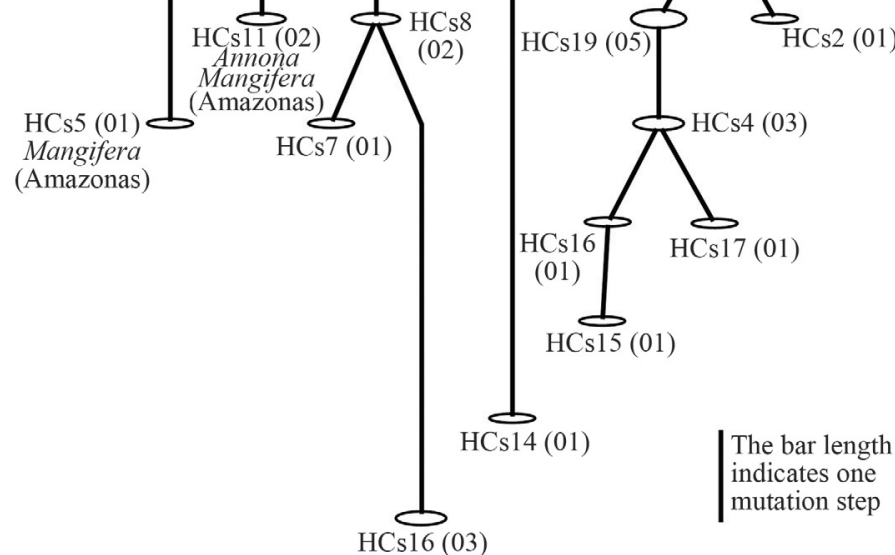

Figure 4 - The ITS-5.8S haplotype network of Ceratobasidium sp. from persimmon (Diospyros kaki) and tea (Camellia sinensis) from São Paulo state, Brazil, showing the most parsimonious plausible $(\sim 95 \%)$ set of connections. The haplotype network was constructed using the statistical parsimony algorithm implemented by TCA (Templeton et al., 1992). The haplotype designations are shown in Table 1. Circle size is proportional to sample size (numbers in parentheses). Two unconnected major clades (the Camellia and Diospyros associated clades) were identified.

Table 2 - Estimates of gene diversity and tests of neutrality for the ITS-rDNA region.

\begin{tabular}{|c|c|c|c|c|c|c|c|c|}
\hline $\begin{array}{l}\text { Populations of } \\
\text { Ceratobasidium sp. }\end{array}$ & $\begin{array}{l}\text { Sequence } \\
\text { length }\end{array}$ & $\begin{array}{l}\text { Total no. of } \\
\text { polymorphic } \\
\text { sites }\end{array}$ & $\begin{array}{l}\text { Polymorphic } \\
\text { sites per } \\
\text { population }\end{array}$ & Haplotypes $^{\mathrm{a}}$ & $\begin{array}{c}\text { Haplotype } \\
\text { diversity } \\
( \pm \mathrm{SD})\end{array}$ & $\begin{array}{c}\text { Fu and Li's } \\
D^{*}\end{array}$ & $\begin{array}{l}\text { Fu and } \\
\text { Li's } F^{*}\end{array}$ & Tajima's $D$ \\
\hline Locus: ITS-5.8S rDNA & $645(628)^{\mathrm{b}}$ & $49(32)^{b}$ & & & & & & \\
\hline $\begin{array}{l}\text { Tea (Camellia sinensis), } \\
\text { Registro, SP }\end{array}$ & & & 10 & $8(64)$ & $0.630 \pm 0.039$ & $-2.4941^{*}$ & $-2.5778^{*}$ & $-1.5649^{\mathrm{ns}}$ \\
\hline $\begin{array}{l}\text { Persimmon (Diospyros } \\
\text { kaki), Guararema, SP }\end{array}$ & & & 7 & $6(64)$ & $0.524 \pm 0.061$ & $-0.4041^{\mathrm{ns}}$ & $-0.7275^{\mathrm{ns}}$ & $-1.0584^{\mathrm{ns}}$ \\
\hline
\end{tabular}

${ }^{a}$ The numbers in parentheses indicate the total number of sequences sampled from each population.

${ }^{\mathrm{b}}$ The numbers in parentheses indicate the length of the compatible sequence alignments and the number of polymorphic sites in the compatible alignments (see Table S2 for further details).

${ }^{*} \mathrm{p}<0.05 ; \mathrm{ns}=$ not significant.

consistent with them being neutral variants that are being spread by homogenization (Ganley and Kobayashi, 2007)], we hypothesized that the deviation from neutrality was due to a change in effective population size. The $g$ values were positive for the Camellia- and Diospyrus-associated clades, indicating population growth (Table 3). However, the growth rate for the Camellia-associated clade was 4.1 times higher than $g$ for the Diospyrus-associated clade. The $g$ values were not symmetrical in magnitude because of an exponential effect on population growth. Thus, a $g$ value that is four times higher would indicate faster growth. This faster population growth was probably the cause of the non-neutral evolution of the ITS rDNA region detected in the Camellia-associated clade. 
Table 3 - Estimates of coalescent parameters from the divergence between tea and persimmon populations of the white-thread-blight and black rot fungus Ceratobasidium sp. based on the ITS-5.8S rDNA region.

\begin{tabular}{|c|c|c|c|c|c|}
\hline \multirow[t]{2}{*}{ Populations } & \multirow{2}{*}{$\begin{array}{l}\text { Haplotypes sampled and } \\
\text { effective sample size }\end{array}$} & \multirow{2}{*}{$\begin{array}{l}\text { Ancestral theta } \\
\qquad(4 \mathrm{Ne} \mu)^{\mathrm{a}}\end{array}$} & \multirow{2}{*}{$\begin{array}{l}\text { Population growth } \\
\text { rate }(\mathrm{g})^{\mathrm{b}}\end{array}$} & \multicolumn{2}{|c|}{ Migration rate ${ }^{\mathrm{c}} 4 \mathrm{Nm}(+=$ receiving population $)$} \\
\hline & & & & $1,+$ & $2,+$ \\
\hline 1. Tea (Camellia) & $8(64)$ & 0.0111 & 248.17 & - & $1.43 \mathrm{e}-07$ \\
\hline $\begin{array}{l}\text { 2. Persimmon } \\
\text { (Diospyrus) }\end{array}$ & $6(64)$ & 0.0074 & 60.16 & 0.3794 & - \\
\hline
\end{tabular}

${ }^{a}$ Theta values represent a measure of effective population size (for diploids, theta $=4 N \mathrm{e} \mu$ where $N \mathrm{e}=$ effective population size and $\mu=$ mutation rate inferred for the locus).

${ }^{b}$ Most probable estimate of population growth rate calculated by Bayesian analyses using the program Lamarc 2.0 (Kuhner, 2006; Kuhner and Smith, 2007).

${ }^{\mathrm{c}}$ Migration between geographical or host populations was estimated using an isolation with migration model. The theta values and migration rates were estimated using the program MIGRATE 2.1.3 (Beerli and Felsenstein, 2001). Sink populations are shown on the left side and source populations are indicated along the top. Effective sample size for each population is given in parentheses. The estimates of population growth, theta and migration rates are at the $95 \%$ confidence interval.

A value of $\mathrm{p}<0.0001$ for the Hudson test estimates $\left(\mathrm{K}_{\mathrm{ST}}=0.89, \mathrm{~K}_{\mathrm{S}}=0.93, \mathrm{~K}_{\mathrm{T}}=8.30\right)$ indicated that the Ceratobasidium populations in tea and persimmon were genetically differentiated (Hudson et al., 1992). However, there was evidence for asymmetric historical migration of Ceratobasidium sp. from the tea population into the persimmon population $\left(4 N_{\mathrm{m} 1,+2}=0.38\right)$ (Table 3$)$.

The coalescent gene genealogy (Figure 5) was used to infer the mutational history of the ITS-5.8S rDNA and to describe the history of the variation observed between the Diospyros- and Camellia-associated clades of Ceratobasidium sp. All of the mutations along the branches were population-specific. Based on coalescent simulations of the estimated mutation age (measured as coalescent units of effective population size $4 \mathrm{Ne} \mu$ and expressed as the time to the most recent common ancestor or $T_{\mathrm{MRCA}}$ ), the oldest mutations were in the Diospyros clade of Ceratobasidium sp. Mutation number 11 was the oldest in the genealogy, with a mean age of $0.94 \pm 0.12$ (SD) coalescent units. This clade also had six of the oldest mutations observed in the genealogy. The haplotypes from the Diospyros clade accumulated an average of 11-13 mutations. In addition, the persimmon-derived population of Ceratobasidium sp. showed a more recent expansion that occurred at $\sim 0.23$ units of coalescent time. The oldest mutation in the Camellia-associated clade was number 9 (Figure 5; mean age: $0.54 \pm 0.05$ coalescent units), which was more recent than the first six mutations in the Diospyros-associated clade. The ITS-5.8S haplotypes of the Camellia-associated clade accumulated a lower number of mutations (4-6) along the genealogy. The time for population expansion (around 0.3 units) was similar to that for the Diospyros clade.

The initial diversification of the white-thread blightassociated Ceratobasidium sp. into two major clades dates to approximately 7.6-14.5 thousand years ago, according to the coalescent approach implemented in the program BEAST 1.2 (Figure 6). The diversification within clades began more recently and, interestingly, the two major clades Camellia and Diospyrus appear to have diversified almost simultaneously between 1.7 and 3.2 thousand years ago (Figure 6). The scenario for the species complex presented by the Bayesian skyline plot showed a dual pattern: a long history of constant population size followed by a very recent expansion (Figure 6) estimated to have occurred about 1-2 thousand years ago. Since then, the populations have expanded in size by approximately four-fold.

\section{Shared mitochondrial haplotypes}

The estimates of mtDNA polymorphism at three distinct loci (ATP6, nad1 and nad2) indicated very little or no variation within and between the two populations of Ceratobasidium sp. (Cs and Dk). A single, shared haplotype was detected for nadl and nad2 genes in both populations, while for ATP6 two out of three haplotypes were shared and only three polymorphic sites [average number of nucleotide differences $(\mathrm{k})=1.06]$ were detected among $660 \mathrm{bp}$ (Table 4). We contrasted the divergence observed between the Cs and Dk populations with the divergence between two sister species within the Thanatephorus complex (which has $R$. solani anamorphs): $R$. solani anatomosis group AG-1 IA ( $R s$ AG-1 IA) and IB (Rs AG-1 IB). No shared haplotypes were observed between $R s$ AG-1 IA and IB for any of the three mtDNA markers, and $\mathrm{k}$ varied from 0.57 (for $n a d 2$ ) to 6.4 (for ATP6). Much higher nucleotide diversity was observed when comparing Ceratobasidium with Thanatephorus.

\section{Discussion}

Persimmon and tea crops from the Brazilian Atlantic Forest agroecosystem harbor populations of the Ceratobasidium spp. complex that are genetically distinct from the originally described white-thread blight coffee pathogen $C$. noxium. The phylogenetic analysis described here indicates that the Ceratobasidium species infecting persimmon and tea in Brazil are distinct from each other: they most likely represent two distinct species within Ceratobasidium and are distinguishable from all the other 


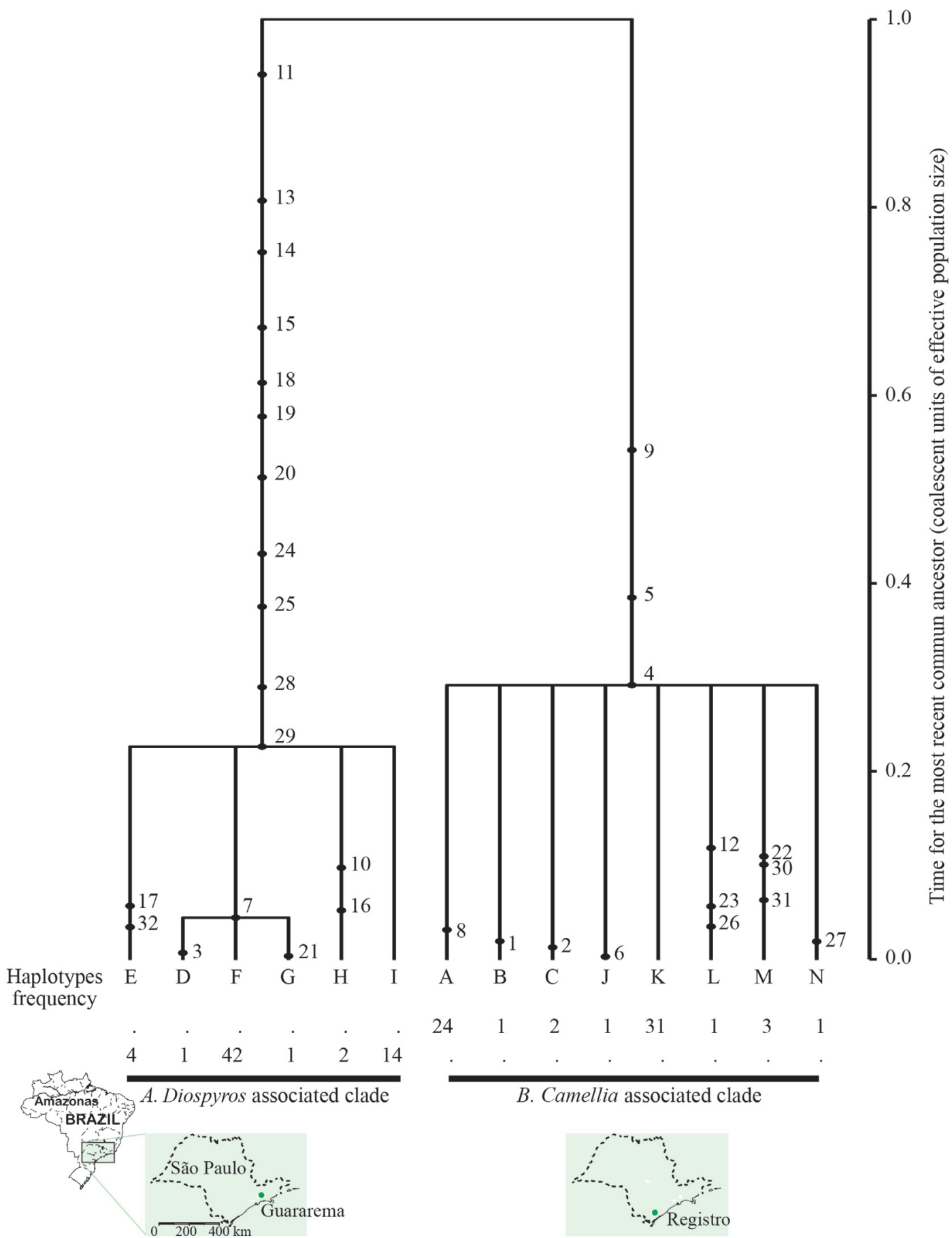

Figure 5 - Coalescent-based gene genealogy with the highest root probability (likelihood $=2.4362$ e-49, SD $=1.0704$ e-49) showing the distribution of ITS-5.8S rDNA mutations in populations of Ceratobasidium sp. from persimmon (Diospyros-associated clade) and tea (Camellia-associated clade). The inferred genealogy was based on Watersons estimate of $\Theta=1.905$ and constant population size and growth rates. The time scale is represented in coalescent units of effective population size. All of the mutations and bifurcations in this rooted genealogy are time ordered from top (past) to bottom (present) and follow the direction of divergence from the oldest to the youngest. The coalescent process is from the bottom to the top of the Figure. The numbers below the tree indicate each distinct haplotype and its frequency, i.e., the number of occurrences of the haplotype in the samples from Diospyros and Camellia. The haplotype designations are given in Table 1.

Ceratobasidium species that cause thread blight disease worldwide.

In addition to the phylogenetic evidence (based on ML, MP and Bayesian MCMCMC analyses) for rejecting the null hypothesis that the two host-specific populations of Ceratobasidium sp. belong to a single species, there were other consistent indications that supported the subdivision between populations of Ceratobasidium from persimmon 


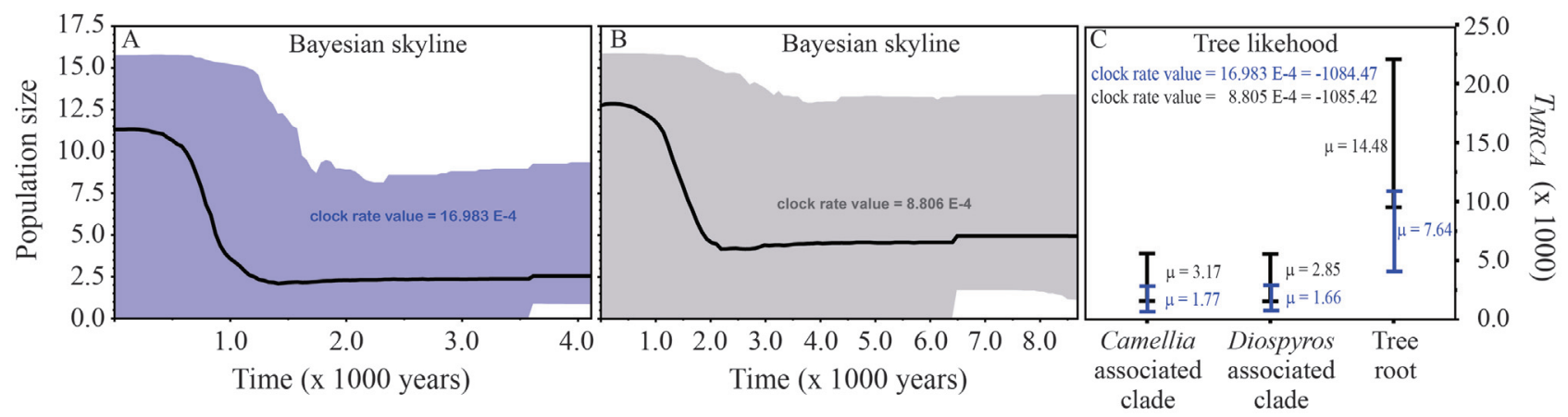

Figure 6 - Bayesian skyline plot (Drummond et al., 2005; Drummond and Rambaut, 2006) showing the effective population size fluctuation over time for the combined Ceratobasidium sp. populations from persimmon (Diospyros-associated clade) and tea (Camellia-associated clade). (a) clock rate $=$ $16.983 e^{-4}$ substitutions/gene $* 10^{3}$ years, (b) clock rate $=8.806 e^{-4}$ substitutions/gene* $10^{3}$ years, (c) tree likelihood values and the $T_{\text {MRCA }}$ under the two distinct clock rates suggested by Kasuga et al. (2002) for the ITS rDNA region of fungi; $\mu$ is the mean $T_{M R C A}$.

and tea, including the lack of shared ITS-5.8S haplotypes (Figure 3 and 4), mutations restricted to one or the other population and no recent migration between Ceratobasidium sp. haplotypes from the Diospyros- and Camellia-associated clades. We detected only historical asymmetric migration of Ceratobasidium from the tea to the persimmon population. This data on asymmetric historical migration was interpreted as evidence for ancestral polymorphisms shared by the Ceratobasidium populations from persimmon and tea, but with little or no recent genetic exchange.

Divergent lineages of parasites can arise through ecological adaptations (Couch et al., 2005; Huyse et al., 2005). For fungal plant parasites, these ecological adaptations include host shifts or changes in pathogenicity (Couch et al., 2005). Host specialization is common in plant pathogenic fungi, such as Magnaporthe grisea (Couch and Kohn, 2002; Couch et al., 2005), Mycosphaerella graminicola (Stukenbrock et al., 2007), Rhynchosporium secalis (Zaffarano et al., 2008), Ceratocystis fimbriata (Baker et al., 2003), Microbotryum violaceum (Bucheli et al., 2000) and Rhizoctonia solani (Ceresini et al., 2007; Bernardes-deAssis et al., 2008). There was no cross pathogenicity between Ceratobasidium isolates from the persimmon and tea groups or from citrus and coffee (two other host plants) (Costa-Souza et al., 2009). However, although in the latter two host plants the fungus did not cause the extensive foliar lesions typically observed in the original host plants, about 30 days after inoculation the fungus showed mycelial growth on the branches of all the other host plants tested. This may indicate that ecological speciation via host specialization has occurred, but with the fungus retaining a broader host range that likely includes reservoir hosts.

There was a high level of genetic diversity in the two local Brazilian populations of Ceratobasidium sp., which in theory would contradict the level of genetic diversity expected for an introduced pathogen. Introduced plant pathogens usually experience a decrease in the genetic diversity of their populations when compared with the variation ob- served at the centre of origin (McDonald and Linde, 2002a,b). There are three plausible explanations for the high level of genetic diversity observed in the persimmon and tea populations of Ceratobasidium sp.: (a) the two populations of Ceratobasidium sp. may have experienced recent diversification following the normal phenomenon of a reduction in genetic diversity associated with introduced pathogens, (b) the establishment of these two crops in Brazil resulted in the introduction of multiple pathogen genotypes from their original centre of diversity in Asia, and (c) the WTBR pathogen originated locally from native hosts, in which a high degree of genetic diversity already existed.

There is little information concerning the pattern of genetic variation in the mtDNA of Ceratobasidium and Thanatephorus species (with Rhizoctonia-like anamorphs). The findings described here are the first for these Basidiomycota and show variation in three mtDNA regions, two of which were novel loci ( $\mathrm{ad} 1$ and nad2). There was little intraspecific variation in mtDNA within and between the two populations of white-thread-blight-fungus Ceratobasidium sp. when compared with nuclear region ITS-rDNA. Lower genetic variation in mtDNA has been reported for several other fungal species, including a few Basidiomycota (Xu et al., 1998; Moncalvo et al., 2000; Carlisle et al., 2001; Ghimire et al., 2003; Zhan et al., 2003; Láday et al., 2004), but there are few exceptions (Sommerhalder et al., 2007).

The low levels of intraspecific variation in mtDNA observed in Ceratobasidium sp. from persimmon and tea may reflect the slow rates of nucleotide substitution in these regions, as reported for fungi in general (Clark-Walker, 1991; Moncalvo et al., 2000). This low variation means that the mtDNA sequences used here cannot be relied on to reveal differences between closely related species, although their potential use in phylogenetic analyses of more divergent species cannot be excluded. Much higher variation was observed by contrasting two divergent phylospecies within Thanatephorus and between Thanatephorus and Ceratobasidium (Table 4). Other mitochondrial genes 
Table 4 - Estimates of within population mtDNA polymorphism and divergence between the two populations of Ceratobasidium sp. from tea [Camellia sinensis (Cs)] and persimmon [Diospyrus kaki (Dk)] compared with three groups within the sister species complex Thanatephorus cucumeris [anamorphs R. solani AG-1 IA (Rs AG-1 IA) and IB (Rs AG-1 IB).

\begin{tabular}{|c|c|c|c|c|c|}
\hline \multirow[t]{2}{*}{ Locus } & \multicolumn{5}{|c|}{ Populations of Ceratobasidium sp. and T. cucumeris } \\
\hline & Cs & Dk & Cs vs. Dk & $\begin{array}{l}\text { Rs AG-1 IA } v s . \\
R s \text { AG-1 IB }\end{array}$ & $\begin{array}{l}\text { Ceratobasidium (Cs + Dk) vs. Thana- } \\
\text { tephorus (Rs AG-1 IA + Rs AG-1 IB) }\end{array}$ \\
\hline \multicolumn{6}{|l|}{ ATP6 } \\
\hline Number of sequences & 17 & 7 & 24 & 6 & 30 \\
\hline Sequence length analyzed (bp) & 660 & 660 & 660 & 654 & 654 \\
\hline Polymorphic sites & 3 & 2 & 3 & 12 & 72 \\
\hline Average number of nucleotide differences $(\mathrm{k})$ & 0 & 0 & 1.06 & 6.4 & 22.4 \\
\hline Haplotypes & 3 & 2 & 3 & 2 & 5 \\
\hline Shared haplotypes between groups contrasted & - & - & 2 & 0 & 0 \\
\hline \multicolumn{6}{|l|}{ nadl } \\
\hline Number of sequences & 16 & 10 & 26 & 8 & 34 \\
\hline Sequence length analyzed (bp) & 333 & 333 & 333 & 333 & 333 \\
\hline Polymorphic sites & 0 & 0 & 0 & 1 & 4 \\
\hline Average number of nucleotide differences $(\mathrm{k})$ & 0 & 0 & 0 & 0.57 & 1.33 \\
\hline Haplotypes & 1 & 1 & 1 & 2 & 3 \\
\hline Shared haplotypes between groups contrasted & - & - & 1 & 0 & 0 \\
\hline \multicolumn{6}{|l|}{$\operatorname{nad} 2$} \\
\hline Number of sequences & 11 & 9 & 20 & 6 & 26 \\
\hline Sequence length analyzed (bp) & 327 & 327 & 327 & 309 & 309 \\
\hline Polymorphic sites & 0 & 0 & 0 & 11 & 31 \\
\hline Average number of nucleotide differences $(\mathrm{k})$ & 0 & 0 & 0 & 5.27 & 9.72 \\
\hline Haplotypes & 1 & 1 & 1 & 2 & 3 \\
\hline Shared haplotypes between groups contrasted & - & - & 1 & 0 & 0 \\
\hline
\end{tabular}

[such as mitochondrial small subunit (mitSSU) rDNA and genes coding for subunits 1 and 3 of the cytochrome oxidase (cox 1 and cox3, respectively)] have been used to resolve deeply branching metazoan/fungal relationships (Paquin et al., 1995, 1997; Forget et al., 2002) and could be exploited as markers for resolving phylogenetic relationships among Ceratobasidium species and/or among sister species of the genus Thanatephorus.

Another important observation from this study was the pattern of growth associated with these populations of Ceratobasidium sp., i.e., a long history of constant population size followed by very recent expansion estimated to have occurred about 1-2 thousand years ago (Figure 6). This recent population expansion may be explained by one of two alternative scenarios: (1) historically, the pathogen may have co-evolved with its hosts in their centre of origin in China (Wight, 1959, 1962; Barua, 1965) and (2) the pathogen may have originated locally on native hosts in South America and only became a persimmon or tea pathogen after the two crop species were introduced.

The first scenario has to be considered cautiously because we have not characterized Asian populations of the pathogen and there is currently no information to support the occurrence of the WTBR pathogen associated with persimmon and tea in China or other Asian countries. The only report of a similar disease in Asia was on coffee in India (Venkatarayan, 1949). Based on our study, however, the coffee-infecting pathogen is a distinct species from those associated with WTBR on persimmon and tea.

The second scenario predicts that the establishment and development of persimmon and tea crops in Brazil led to the emergence of a new pathogen through local adaptation in already existing highly variable Ceratobasidium sp. populations. The changes in population size would have occurred in local pathogen populations infecting native plant species. The incidence of WTBR in several native plant species from the Amazon (Lourd and Alves, 1987; Gasparotto and Silva, 1999; Benchimol et al., 2001) supports the hypothesis of a local origin for the populations of Ceratobasidium from persimmon and/or tea. Indeed, we have detected two ITS-5.8S rDNA haplotypes in the $\mathrm{Ca}$ mellia-associated clade of Ceratobasidium that were similar to haplotypes detected in soursop and mango isolates from the Amazon. However, based on the data described here, we cannot confidently postulate that the changes de- 
tected in demographic parameters were necessarily determined by the local origin of the pathogen.

To examine the influence of the local origin for this pathogen and to assess the changes in demographic parameters it will be necessary to sample other Brazilian populations of the pathogen. These samples should include populations of Ceratobasidium sp. from other crops (such as coffee, citrus and rubber trees), from crops adjacent to persimmon and tea plantations and, most importantly, from native plants from other locations such as the Atlantic and the Amazonian forests adjacent to agroecosystems. Such a framework is critical to understanding the origins and evolution of WTBR-associated Ceratobasidium spp. as pathogens of many important tropical tree species.

Based on the results of this work, we conclude that the two sister populations of the basidiomycetous fungus Ceratobasidium sp. from persimmon and tea in the Brazilian Atlantic Forest agroecosystem represent two distinct, historically divergent lineages that have experienced historical diversification. These two Brazilian populations of the WTBR fungus most likely represent distinct species within Ceratobasidium and they are also distinct from $C$. noxium (the etiological agent of the white-thread blight in coffee firstly described in India), and C. cornigerum (the most closely related species).

\section{Acknowledgments}

E.C.S. was supported by an MSc scholarship from Coordenação para Aperfeiçoamento de Pessoal do Ensino Superior (CAPES). E.L.F., P.C.C. and N.L.S. are supported by research fellowships from Conselho Nacional de Desenvolvimento Científico e Tecnológico (CNPq). This work was supported by a grant from Fundação de Amparo à Pesquisa do Estado de São Paulo (FAPESP, grant no. 04/1980-0) to P.C.C.

\section{References}

Altschul S, Madden T, Schaffer A, Zhang J, Zhang Z, Miller W and Lipman D (1997) Gapped BLAST and PSI-BLAST: A new generation of protein database search programs. Nucleic Acids Res 25:3389-3402.

Aylor DL, Price EW and Carbone I (2006) SNAP: Combine and Map modules for multilocus population genetic analysis. Bioinformatics 22:1399-1401.

Baker CJ, Harrington TC, Krauss U and Alfenas AC (2003) Genetic variability and host specialization in the Latin American clade of Ceratocystis fimbriata. Phytopathology 93:1274-1284.

Barua D (1965) Classification of the tea plant: Species hybrids. Two and a Bud 12:13-27.

Beerli P and Felsenstein J (2001) Maximum likelihood estimation of a migration matrix and effective population sizes in $\mathrm{N}$ subpopulations by using a coalescent approach. Proc Natl Acad Sci USA 98:4563-4568.
Benchimol RL, Poltronieri LS, Trindade DR and Albuquerque FC (2001) White-thread blight: Five new hosts in the state of Pará, Brazil. Fitopatol Bras 26:778-778.

Bernardes-de-Assis J, Peyer P, Zala M, Rush M, McDonald BA and Ceresini PC (2008) Divergence between sympatric riceand soybean-infecting populations of Rhizoctonia solani AG-1 IA. Phytopathology 98:1326-1333.

Bucheli E, Gautschi B and Shykoff JA (2000) Host-specific differentiation in the anther smut fungus Microbotryum violaceum as revealed by microsatellites. J Evol Biol 13:188-198.

Carbone I and Kohn LM (2001) A microbial population-species interface: Nested cladistic and coalescent inference with multilocus data. Mol Ecol 10:947-964.

Carlisle D, Cooke LR and Brown AE (2001) Phenotypic and genotypic characterization of Northern Ireland isolates of Phytophthora infestans. Eur J Plant Pathol 107:291-303.

Ceresini PC and Souza NL (1996) Caracterização cultural e fisiológica de Rhizoctonia solani GA-4 HGI associado a vagens de amendoinzeiro. Fitopatol Bras 21:443-454.

Ceresini PC, Shew HD, James TY, Vilgalys RJ and Cubeta MA (2007) Phylogeography of the solanaceae-infecting Basidiomycota fungus Rhizoctonia solani AG-3 based on sequence analysis of two nuclear DNA loci. BMC Evol Biol 7:e163.

Ciampi MB, Kuramae EE, Fenille RC, Meyer MC, Souza NL and Ceresini PC (2005) Intraspecific evolution of Rhizoctonia solani AG-1 IA associated with soybean and rice in Brazil based on polymorphisms at the ITS-5.8S rDNA operon. Eur J Plant Pathol 113:183-196.

Clark-Walker GD (1991) Contrasting mutation rates in mitochondrial and nuclear genes of yeast versus mammals. Curr Genet 20:195-198.

Clement M, Posada D and Crandall KA (2000) TCS: A computer program to estimate gene genealogies. Mol Ecol 9:16571659.

Costa-Souza E, Basseto M, Boliani AC, Takada H and Ceresini P (2009) Patogenicidade cruzada de Ceratobasidium spp. do caquizeiro (Diospyros kaki) e do chá (Camellia sinensis) e reação de cultivares de caqui ao patógeno. Summa Phytopathol 35:9-14.

Couch BC and Kohn LM (2002) A multilocus gene genealogy concordant with host preference indicates segregation of a new species, Magnaporthe oryzae, from M. grisea. Mycologia 94:683-693.

Couch BC, Fudal I, Lebrun M-H, Tharreau D, Valent B, van Kim P, Notteghem J-L and Kohn L (2005) Origins of hostspecific populations of the blast pathogen, Magnaporthe oryzae, in crop domestication with subsequent expansion of pandemic clones on rice and weeds of rice. Genetics 170:613-630.

Donk M (1954) Notes on resupinate Hymenomycetes - I. On Pellicularia Cooke. Reinwardtia 2:425-434.

Drummond AJ, Rambaut A, Shapiro B and Pybus OG (2005) Bayesian coalescent inference of past population dynamics from molecular sequences. Mol Biol Evol 22:1185-1192.

Fawcett GL (1914) Pellicularia koleroga on coffee in Puerto Rico. J Agric Res 2:231-233.

Forget L, Ustinova J, Wang Z, Huss VAR and Lang BF (2002) Hyaloraphidium curvatum: A linear mitochondrial genome, 
tRNA editing, and an evolutionary link to lower fungi. Mol Biol Evol 19:310-319.

Fu YX and Li WH (1993) Statistical tests of neutrality of mutations. Genetics 133:693-709.

Furtado E (1997) Doenças do chá. In: Kimati H, Amorim L, Bergamim Filho A, Camargo L and Rezende J (eds) Manual de Fitopatologia. 3rd edition. Agronômica Ceres, São Paulo, pp 257-260.

Ganley ARD and Kobayashi T (2007) Highly efficient concerted evolution in the ribosomal DNA repeats: Total rDNA repeat variation revealed by whole-genome shotgun sequence data. Genome Res 17:184-191.

Gasparotto L and Silva SEL (1999) New hosts of Pellicularia koleroga in the State of Amazonas, Brazil. Fitopatol Bras 24:469.

Ghimire SR, Hyde KD, Hodgkiss IJ, Shaw DS and Liew ECY (2003) Variations in the Phytophthora infestans population in Nepal as revealed by nuclear and mitochondrial DNA polymorphisms. Phytopathology 93:236-243.

Gonzalez D, Carling DE, Kuninaga S, Vilgalys R and Cubeta MA (2001) Ribosomal DNA systematics of Ceratobasidium and Thanatephorus with Rhizoctonia anamorphs. Mycologia 93:1138-1150.

Griffiths RC and Tavaré S (1994) Sampling theory for neutral alleles in a varying environment. Phil Trans R Soc Lond B Biol Sci 344:403-410.

Griffiths RC and Tavaré S (1996) Markov chain inference methods in population genetics. Math Comput Model 23:141158

Gutierrez W, Shew H and Melton T (1998) Sources of inoculum and management for Rhizoctonia solani damping-off on tobacco transplants under greenhouse conditions. Plant Dis $81: 35$.

Herr L and Roberts D (1980) Characterization of Rhizoctonia solani populations obtained from sugar beet fields with differing soil textures. Phytopathology 70:476-480.

Hudson R, Boos D and Kaplan N (1992) A statistical test for detecting geographic subdivision. Mol Biol Evol 9:138-151.

Huelsenbeck JP and Ronquist F (2001) MRBAYES: Bayesian inference of phylogenetic trees. Bioinformatics 17:754-755.

Huyse T, Poulin R and Theron A (2005) Speciation in parasites: A population genetics approach. Trends Parasitol 21:469-475.

James TY, Moncalvo JM, Li S and Vilgalys R (2001) Polymorphism at the ribosomal DNA spacers and its relation to breeding structure of the widespread mushroom Schizophyllum commune. Genetics 157:149-161.

Kasuga T, White TJ and Taylor JW (2002) Estimation of nucleotide substitution rates in Eurotiomycete fungi. Mol Biol Evol 19:2318-2324.

Kretzer AM and Bruns TD (1999) Use of atp6 in fungal phylogenetics: An example from the Boletales. Mol Phylogenet Evol 13:483-492.

Kuhner MK (2006) LAMARC 2.0: Maximum likelihood and Bayesian estimation of population parameters. Bioinformatics 22:768-770.

Kuhner MK and Smith LP (2007) Comparing likelihood and Bayesian coalescent estimation of population parameters. Genetics 175:155-165.

Láday M, Juhász Á, Mulè G, Moretti A, Szécsi Á and Logrieco A (2004) Mitochondrial DNA diversity and lineage determina- tion of European isolates of Fusarium graminearum (Gibberella zeae). Eur J Plant Pathol 110:545-550.

Lourd M and Alves B (1987) Lista de hospedeiro e etiologia da queima-do-fio das plantas frutíferas na região Amazônica. Fitopatol Bras 12:88-89.

McDonald BA and Linde C (2002a) Pathogen population genetics, evolutionary potential, and durable resistance. Annu Rev Phytopathol 40:349-379.

McDonald BA and Linde C (2002b) The population genetics of plant pathogens and breeding strategies for durable resistance. Euphytica 124:163-180.

Moncalvo J-M, Drehmel D and Vilgalys R (2000) Variation in modes and rates of evolution in nuclear and mitochondrial ribosomal DNA in the mushroom genus Amanita (Agaricales, Basidiomycota): Phylogenetic implications. Mol Phylogenet Evol 16:48-63.

Paquin B, Forget L, Roewer I and Lang BF (1995) Molecular phylogeny of Allomyces macrogynus: Congruency between nuclear ribosomal RNA- and mitochondrial protein-based trees. J Mol Evol 41:657-665.

Paquin B, Laforest M-J, Forget L, Roewer I, Wang Z, Longcore J and Lang BF (1997) The fungal mitochondrial genome project: Evolution of fungal mitochondrial genomes and their gene expression. Curr Genet 31:380-395.

Pereira RCA, Ledo FJS, Bergo CL and Siviero A (2000) Evaluation of arabica and robusta coffee genotypes in western Amazonia. Acta Amazonica 30:535-541.

Pereira RCA, Takada HM, Ribeiro IJA, Bueno SCS, Yanagisawa SS, Freire ILC, Santos MC and Timóteo WS (2003) Registro da queima dos fios (Ceratobasidium sp.) em caqui (Diospyros kaki). Fitopatol Bras 28:90.

Posada D and Crandall KA (1998) MODELTEST: Testing the model of DNA substitution. Bioinformatics 14:817-818.

Posada D and Crandall KA (2001) Intraspecific gene genealogies: Trees grafting into networks. Trends Ecol Evol 16:37-45.

Price EW and Carbone I (2005) SNAP: Workbench management tool for evolutionary population genetic analysis. Bioinformatics 21:402-404.

Roberts P (1999) Ceratobasidium noxium (Donk) In: Roberts P (ed) Rhizoctonia-Forming Fungi: A Taxonomic Guide. Kew Publishing, Kew, pp 246.

Rogers D (1943) The genus Pellicularia (Thelephoraceae). Farlowia 1:95-118

Rosseti V, Alves M and Clement C (1982) Ocorrência de Pellicularia koleroga em pomares cítricos na Amazonia. Fitopatol Bras 7:526.

Rozas J, Sánchez-DelBarrio JC, Messegyer X and Rozas R (2003) DnaSP, DNA polymorphism analyses by the coalescent and other methods. Bioinformatics 19:2496-2497.

Sneh B, Burpee L and Ogoshi A (1991) Identification of Rhizoctonia Species. The American Phytopathological Society, Saint Paul, 133 pp.

Sommerhalder RJ, McDonald BA and Zhan J (2007) Concordant evolution of mitochondrial and nuclear genomes in the wheat pathogen Phaeosphaeria nodorum. Fungal Genet Biol 44:764-772.

Stukenbrock EH, Banke S, Javan-Nikkhah M and McDonald BA (2007) Origin and domestication of the fungal wheat pathogen Mycosphaerella graminicola via sympatric speciation. Mol Biol Evol 24:398-411. 
Tajima F (1989) Statistical method for testing the neutral mutation hypothesis by DNA polymorphism. Genetics 123:585-595.

Talbot P (1965) Studies of Pellicularia and associated genera of Hymenomycetes. Persoonia 3:371-406.

Templeton AR, Crandall KA and Sing CF (1992) A cladistic analysis of phenotypic associations with haplotypes inferred from restriction endonuclease mapping and DNA sequence data. III. Cladogram estimation. Genetics 132:619-633.

Thompson J, Higgins D and Gibson T (1994) CLUSTAL W. Improving the sensitivity of progressive multiple sequence alignment through sequence weighting, position-specific gap penalties and weight matrix choice. Nucleic Acids Res 22:4673-4680.

Thompson J, Gibson T, Plewniak F, Jeanmougin F and Higgins D (1997) The Clustal X Windows interface: Flexible strategies for multiple sequence alignment aided by quality analysis tools. Nucleic Acids Res 25:4876-4882.

Tims EC, Mills PJ and Exner B (1954) Thread-blight (Pellicularia koleroga) in Louisiana. Plant Dis 38:634-637.

Venkatarayan S (1949) The validity of the name Pellicularia koleroga Cooke. Indian Phytopath 2:186-189.

White TJ, Bruns T, Lee S and Taylor JW (1990) Amplification and direct sequencing of fungal ribosomal RNA genes for phylogenetics. In: Innis MA, Gelfand DH, Sninsky JJ and White TJ (eds) PCR Protocols: A Guide to Methods and Applications. Academic Press, New York, pp 315-322.

Wight W (1959) Nomenclature and classification of the tea plant. Nature 183:1726-1728.

Wight W (1962) Tea classification revised. Curr Sci 31:298-299.

Xu J, Kerrigan RW, Sonnenberg AS, Callac P, Horgen PA and Anderson JB (1998) Mitochondrial DNA variation in natural populations of the mushroom Agaricus bisporus. Mol Ecol 7:19-33.

Zaffarano PL, McDonald BA and Linde CC (2008) Rapid speciation following recent host shifts in the plant pathogenic fungus Rhynchosporium. Evolution 62:1418-1436.

Zhan J, Pettway RE and McDonald BA (2003) The global genetic structure of the wheat pathogen Mycosphaerella graminicola is characterized by high nuclear diversity, low mitochondrial diversity, regular recombination, and gene flow. Fungal Genet Biol 38:286-297.

\section{Internet Resources}

CAB-International (2004) Corticium koleroga (Cooke) Höhn. $\mathrm{CAB}$ International, Wallingford. Http://www.indexfungorum.org/Names/synspecies.asp?Re cordID $=120730$ (June 15, 2011).

Cavalcante M and Sales F (2001) Ocorrência da queima-do-fio (Pellicularia koleroga) em cafezais em Rio Branco. Empresa Brasileira de Pesquisa Agropecuaria - Embrapa Acre, Rio Branco. http://catuaba.cpafac.embrapa.br/ pdf/comunicado135.pdf (June 15, 2011).

Drummond AJ and Rambaut A (2006) BEAST 1.4. University of Oxford, Department of Zoology. http://beast.bio. ed.ac.uk/Main_Page (June 15, 2011).

Swofford DL (2002) PAUP* 4.0: Phylogenetic Analysis Using Parsimony. Sinauer Associates, Inc. , Champaign, IL. http://paup.csit.fsu.edu/downl.html (June 15, 2011).

$\mathrm{Fu}$ genealogy test, available from http://hgc.sph.uth. tmc.edu/fu/genealogy/test2/welcome.html.

\section{Supplementary Material}

The following online material is available for this article:

Figure S1 - Symptoms of white-thread blight and black rot and signs of Ceratobasidium sp. on persimmon and tea plants.

Table S1- Degenerate and specific primers designed for PCR amplification and sequencing reactions.

Table S2 - Characterization of haplotypes of Ceratobasidium sp. from persimmon and tea.

This material is available as part of the online article at: http://www.scielo.br/gmb.

Associate Editor: Juan Lucas Argueso

License information: This is an open-access article distributed under the terms of the Creative Commons Attribution License, which permits unrestricted use, distribution, and reproduction in any medium, provided the original work is properly cited. 

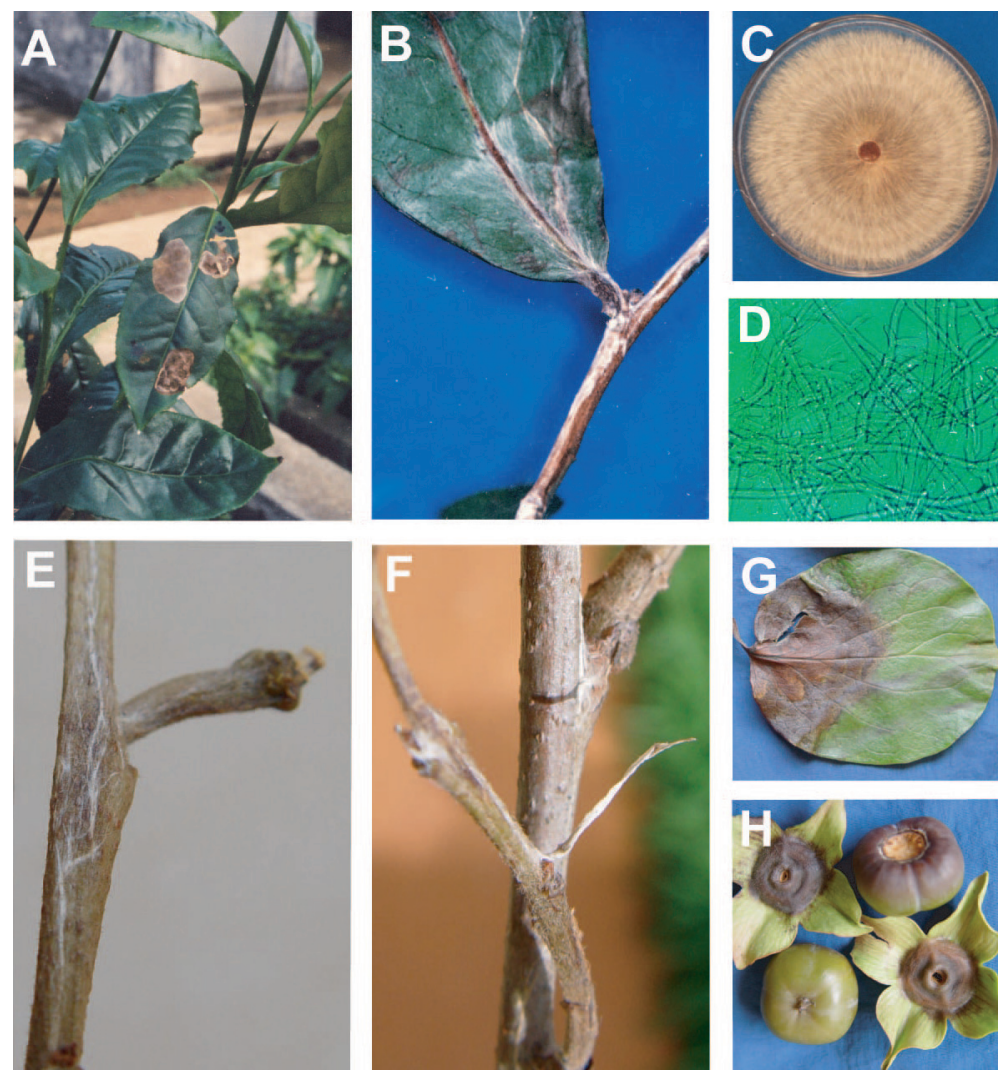

Figure S1 - Symptoms of white-thread blight and black rot and signs of Ceratobasidium sp. on persimmon and tea plants, respectively.

- Symptoms of black rot on tea (A), white-thread blight on persimmon leaves $(\mathrm{G})$ and fruits $(\mathrm{H})$.

- Mycelial growth (B, E) and mycelial cord (B) on tea and persimmon (F) branches.

- Hyphae and mycelial growth of Ceratobasidium sp. on potato-dextrose-agar medium (C, D). 
Table S1 - Degenerate and specific primers designed for PCR amplification and sequencing reactions of three mtDNA fragments from the Basidiomycota fungus Ceratobasidium

\begin{tabular}{|c|c|c|c|c|c|c|c|c|}
\hline \multirow{2}{*}{$\begin{array}{l}\text { NCBI } \\
\text { accession } \\
\text { number }\end{array}$} & \multirow[t]{2}{*}{ Organism } & \multirow{2}{*}{$\begin{array}{l}\begin{array}{l}\text { Mitochondrial } \\
\text { gene and } \\
\text { genomic region }\end{array} \\
\text { NADH } \\
\text { dehydrogenase } \\
\text { subunit } 1 \\
\text { (nad1) }\end{array}$} & \multirow{2}{*}{\multicolumn{2}{|c|}{ Degenerate primers for Basidiomycetes }} & \multicolumn{4}{|c|}{ Gene-specific primers for Ceratobasidium and Thanatephorus } \\
\hline & & & & & Code & $\begin{array}{l}\text { Length } \\
\text { (bp) }\end{array}$ & Oligo & $\begin{array}{l}\text { Length of } \\
\text { PCR } \\
\text { amplicon } \\
\text { (bp) }\end{array}$ \\
\hline AY376688 & $\begin{array}{l}\text { Crinipellis perniciosa mitochondrion, } \\
\text { complete genome }\end{array}$ & $70615-72832$ & nad1_F & 5'-TAGTATTTAGTYTAYTAGG-3' & nad1N_F & 20 & 5'-AGGGTGGGCTGTAATTCCTT-3' & 360 \\
\hline $\begin{array}{l}\text { NC_004336 } \\
\text { AY560608 }\end{array}$ & $\begin{array}{l}\text { Cryptococcus neoformans var. grubii } \\
\text { mitochondrion, complete genome } \\
\text { C. neoformans var. grubii strain IFO } 410\end{array}$ & $\begin{array}{l}18444-18609 \\
19731-20575 \\
221-1066\end{array}$ & nad1_R & 5'-CHTTTGAYCTACMAGARGC-3' & nad1N_R & 22 & 5'-TCTGGTAGGTCAAATGGTGTTC-3' & \\
\hline \multirow[t]{2}{*}{ NC_003049 } & $\begin{array}{l}\text { Schizophyllum commune mitochondrion, } \\
\text { complete genome }\end{array}$ & $28257-29270$ & & & & & & \\
\hline & & $\begin{array}{l}\text { NADH } \\
\text { dehydrogenase } \\
\text { subunit } 2 \\
(\text { nad2) }\end{array}$ & & & & & & \\
\hline AY376688 & $\begin{array}{l}\text { C. perniciosa mitochondrion, complete } \\
\text { genome }\end{array}$ & $65399-67192$ & nad2A_F & 5'-TAAGTATTGAAYTACAATC-3' & nad2N_F & 22 & 5'-AGCCCAACAACTGTACCTATGA-3' & 488 \\
\hline NC_004336 & $\begin{array}{l}\text { C. neoformans var. grubii mitochondrion, } \\
\text { complete genome }\end{array}$ & $37790-39589$ & nad2A_R & 5'-TAGCYTATAGTACMATWTC-3' & nad2N_R & 20 & 5'-TCAGCTACTTCAGCCGGATT-3' & \\
\hline \multirow[t]{4}{*}{ NC_003049 } & $\begin{array}{l}\text { S. commune mitochondrion, complete } \\
\text { genome }\end{array}$ & $15468-16967$ & & & & & & \\
\hline & & $\begin{array}{l}\text { ATP synthase } \\
\text { subunit } 6 \\
(A T P 6)\end{array}$ & & & & & & \\
\hline & & & atp6_2 & 5'-TAATTCTANWGCATCTTTAATRTA- & & & & 727 \\
\hline & & & atp6_3 & 5'-TCTCCTTTAGAACAATTTGA-3' & $*$ & & & \\
\hline
\end{tabular}

*The ATP6 primers used in this study were described by Kretzer and Bruns (1999) for phylogenetic analyses of Basidiomycota fungi. Primer bases presented in blue indicate degenerate bases. 
Table S2 - Characterization of haplotypes of Ceratobasidium sp. from persimmon and tea based on polymorphic sites detected in ITS-rDNA sequences.

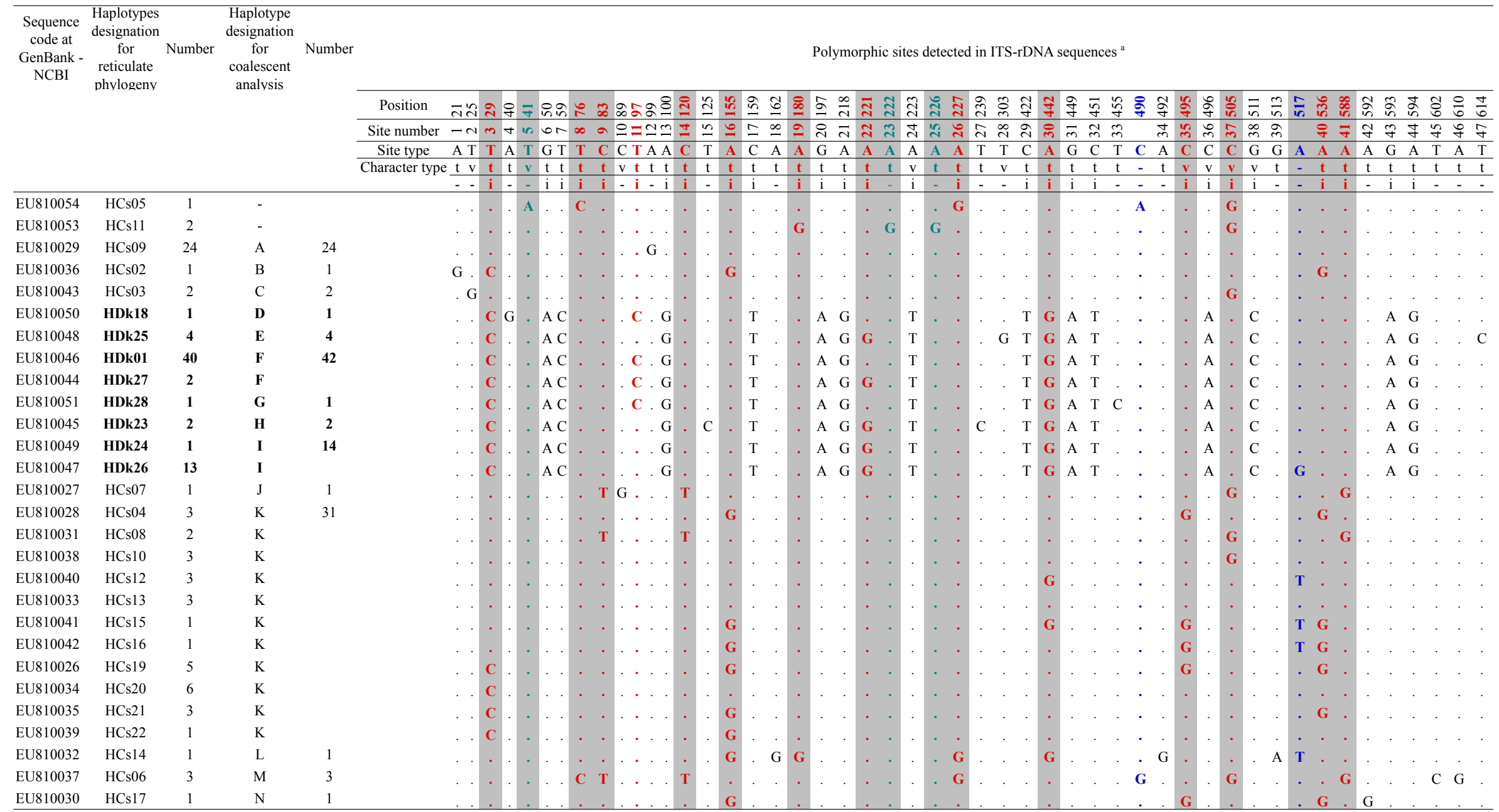




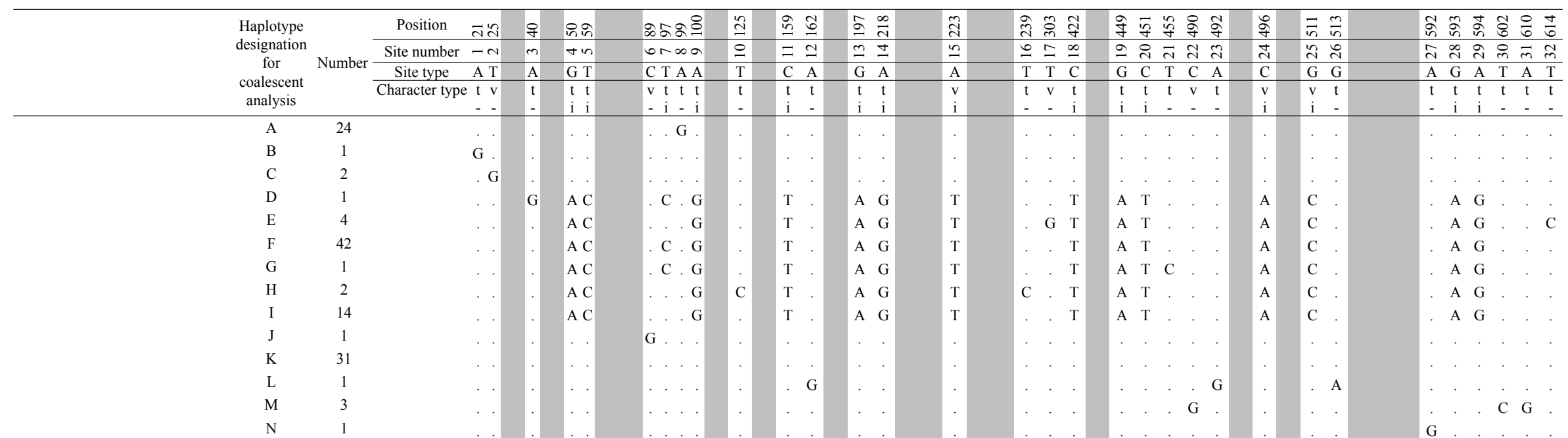

${ }^{a}$ Conflicting sites showing homoplasy are presented in red; these incompatible sites (present among the polymorphic sites) were identified using the compatibility methods SNAP Clade and SNAP Matrix (Figure 2)

Light shading columns indicate conflicting sites removed for the coalescent analyses.

Site type: $\mathrm{t}=$ transition; $\mathrm{v}=$ transversion. Character type: $\mathrm{i}=$ phylogenetically informative; $-=$ uninformative.

Sequences from the ITS-rDNA haplotypes detected in this study were deposited in GenBank/NCBI under accession numbers EU810026 to EU810056. Haplotypes in bold are associated with Diospyrus.

Bases in blue indicate infinite sites violations that were removed from all the analyses and the ones in blue green indicate polymorphisms detected in the haplotypes HCs5 and HCs11 (from Anona muricata and Mangifera indica), which were not included in the coalescent analyses. 